\title{
The Proof is in the History: The LOUISIANA CONSTITUTION RECOGNISES TRANSSEXUAL MARRIAGES AND LOUISIANA SEX DISCRIMINATION LAW COVERS TRANSSEXUALS - SO WHY ISN'T EVERYBOdY CELEBRATING?
}

\author{
KATRINA C ROSE*
}

[Approximately half of the states in the United States of America have statutes recognising the reality of transsexualism. US Attorney and transgender legal historian, Katrina Rose, examines one of the earliest of these, revealing that Louisiana legislators in 1968 clearly understood the difference between gay marriages, and heterosexual marriages in which one spouse is transsexual. Rose also suggests that adoption of such a statute should be viewed expansively, with positive ramifications throughout the state's body of law. Additionally, she offers a scathing critique of the hypocrisy which has long permeated the American gay rights movement's willingness to minimise transgender issues and to avoid treating transsexuals as equals. It is argued that this is no longer mere political polemic as the growing number of sweeping anti-gay constitutional amendments has transformed the history of transgendered people having no voice in the gay-marriage-dominated gay agenda into an essential element of transsexuals' defence where legislative intent of such amendments are an issue in matters involving transsexuals.]

\footnotetext{
* Attorney at Law, licensed in Texas and Minnesota; currently pursuing a Ph.D in History at the University of Iowa; founding member of the National Transgender Advocacy Coalition (NTAC). The author would also like to thank the following individuals who helped in various ways at various stages of the writing of this article: Sandy Stevens, Gwen Smith, Ethan St. Pierre, Professor Mickey Eliason and Alyson Meiselman; and, above all else, thanks to Miss Debra Kate for being Miss Debra Kate.
} 


\section{INTRODUCTION}

\section{A The Setting}

I make jokes about the black people, and why not? Because I'm not one. ${ }^{1}$

On 24 July 2003, the California Senate gave its approval to Assembly Bill 196, ${ }^{2}$ an amendment to that state's Fair Employment and Housing Act ('FEHA]) to forbid discrimination based on gender identity. ${ }^{3}$ On 2 August 2003, prior to his being recalled in favour of Arnold Schwarzenegger, Governor Gray Davis signed the bill. ${ }^{4}$

This enactment is significant not simply in terms of the protection provided by revised statute for transgendered Californians but also because it marks only the second time that the so-called "incremental progress" strategy - of gays getting their rights first while transgendered people are forced to remain without protection from the ravages of discrimination - mandated by gay politicos for the transgendered has actually worked at the state level. ${ }^{5}$

${ }^{1}$ NBC Television (USA), Saturday Night Live, 28 January 1984, monologue of Don Rickles.

${ }^{2}$ Per the Legislative Council:

This bill would expand the prohibition on sexual discrimination and harassment by including gender, as defined, in the definition of sex. The bill would permit employers to require employees to comply with reasonable workplace appearance, grooming, and dress standards consistent with state and federal law, provided that employees are allowed to appear or dress consistently with their gender identity. (emphasis added).

Legislative Counsel's Digest, 2003 CAL. A.B. 196 (emphasis added).

${ }^{3}$ Jim Herron Zamora, 'Senate OKs Gender Identity Bill; It Bans Discrimination Against Transsexuals' San Francisco Chronicle, 25 July 2003; Lisa Leff, 'Senate Passes Bill Outlawing Bias Against Transgendered Resident', Sacramento Bee, 25 July 2003.

${ }^{4}$ TLPI, 'California Governor Signs Historic Anti-Discrimination Bill', (Press Release, 3 August 2003), Available on-line at: 〈http://www.transgenderlaw.org/carelease.htm>.

Subsequently, the California Legislature passed a bill which tidied up diverse provisions of the FEHA and the Labour Code - all of which now include the trans-inclusive language. 'California Passes Gay

Labour Law', 365gay.com, 16 August 2004, Available on-line at:

<http://www.365gay.com/newscon04/08/ 081604calLabor.htm>. In fairness to the Governator, he did sign this bill. 2004 CAL. AB 2900, enacted as, 2004 CAL. LAWS Ch. 788 (approved 24 September 2004).

${ }^{5}$ This concept has worked slightly more often at the county and municipal level. However, the disparity between jurisdictions where gays, but not transgendered people, are afforded a right of redress against discrimination and those that have full inclusion is, over three decades after Stonewall, still depressingly staggering. According to information on the website of the Human Rights Campaign (HRC), the ratio of jurisdictions with sexual orientation protection to those with both sexual orientation and gender identity is 153 to 65 . Moreover, even now some localities propose and pass anti-discrimination ordinances which leave out the segment of the GLBT community that is most in need of anti-discrimination protection. Compare DALLAS, TEXAS CODE § 46-4 (18) (2002) ('Sexual orientation means an individual's real or perceived orientation as heterosexual, homosexual, or bisexual or an individual's real or perceived 
This strategy, if it can truly be called one, has long been assailed by transgendered people. ${ }^{6}$ At best, it is seen as a failed concept, as prior to AB 196, more state legislatures had passed fully-inclusive GLBT rights bills than had ever gone back and rectified non-inclusive statutes. ${ }^{7}$ At worst, the concept is seen as a flat-out lie that was designed to con the transgendered into not bringing to the attention of legislators (those considering gay-only rights proposals) the fact that such laws leave gays and the transgendered legally unequal to each other even though those most apt to discriminate see no difference between the butchest gay male and the most passable, feminine male-to-female transsexual. ${ }^{8}$

A corollary to "incremental progress" is the edict to transgendered people commanding them to eschew the Legisiature in general in favour of utilising existing law to garner favourable court decisions, typically based in some manner on the concept of "gender stereotyping," as recognised by the US Supreme Court in 1989 in Price Waterhouse v Hopkins.

However, this rests on two shaky assumptions: transgendered plaintiffs being able to find competent (or even $a n y^{10}$ ) legal representation and the cases brought by these plaintiffs landing in courts that will actually hear them. Although the Price Waterhouse line of transgender cases is indeed more encouraging than the Holloway $v$ Arthur Andersen ${ }^{11}$ line that it may (or may not) have supplanted, even a number of courts which do look favourably upon the "gender stereotyping" theory have bluntly asserted that a transsexual still would be without recourse if discriminated against specifically because of having a transsexual history, ${ }^{12}$ something that

gender identity.') (trans-inclusive); with FORT WORTH, TEXAS CODE § 17-46 (2004) ('Sexual orientation means: heterosexuality, homosexuality or bisexuality or being identified with such orientation.') (non-trans-inclusive).

${ }^{6}$ Katrina C. Rose, 'Conservaqueers Not Been Vedy, Vedy Good To Us', Texas Triangle, 13 October 2000, Available on-line at: <http://www.txtriangle.com/archive/901/vpkatrose.htm> (last visited 12 September 2004).

${ }^{7}$ With the first American state gay rights statute, Wisconsin's, having never been amended even after 20+ years. 1981 WIS. LAWS Ch. 112.

Minnesota, in 1993, and New Mexico a decade later both were transgender-inclusive in the first instance. See 1993 MINN. LAWS Ch. 22; and 2003 N.M. LAWS Ch. 383. Rhode Island's 1995 gay-only rights law was revised to include the transgendered in 2001. 2001 R.I. LAWS Ch. 340.

8 'Straight-acting' gays should think twice before turning their backs on less mainstream queers. Our enemies don't distinguish between the two.' Maria Helena Dolan, 'Real Fascists Hate Queers', Southern Voice, 25 July 2003; see also John Gallagher, 'For Transsexuals 1994 is 1969', The Advocate, 23 August 1994, 59, 60 (AEGIS Executive Director Dallas Denny, noting a religionist right, trans-inclusive antigay initiative in Washington and observing, 'Those people don't distinguish between us.'). 490 US 228 (1989).

${ }^{10}$ Rudy Serra and Annette E. Skinner, 'Counseling the Gay, Lesbian, or Transgender Client' (2001) 80 Michigan Bar Journal 52.

${ }^{11}$ See Part V

${ }^{12}$ See Smith v City of Salem, 378 F 3d 566 (6 $6^{\text {th }}$ Cir, 2004); and Doe v United Consumer Financial Svcs., No. 1:01 CV 1112 (ND Ohio, 2001) (holding that Title VII can aid a transsexual against employment discrimination but because of gender stereotyping, not because of transsexualism per se). Another recent noteworthy decision is the unpublished Tronetti v TLC Healthnet Lakeshore Hospital. No. 03-CV0375E(Sc), 2003 U.S. Dist. LEXIS 23757 (WD NY, 26 September 2003). Though favourable in that it 
likely would be the case with a deeply-closeted, already-transitioned and fullypassable transsexual who is outed. ${ }^{13}$ And, of course, this definitely would be the case should an employer brazenly post a sign that reads: transsexuals need not apply. Additionally, some federal courts have totally rejected the notion that transgendered people have any place whatsoever in the Price Waterhouse-inspired "gender stereotyping" jurisprudence. ${ }^{14}$ Consequently, in the absence of any enforceable state or local proscription against such discrimination, transgendered people are still for all practical purposes defenceless. ${ }^{15}$

In this article I will examine an area that, curiously in my view, seems to have escaped the notice of those American GLB (and even T) organisations that have touted, often to the exclusion of seeking coverage for transgendered people in proposed new sexual orientation legislation, the utilisation of existing law as the methodology for the transgendered. ${ }^{16}$ What I will propose is what should logically result from transsexual-specific birth certificate statutes being read in conjunction with state statutes proscribing discrimination based on sex. The potential in such a reading is significant not only in and of $\operatorname{itself}^{17}$ but also because it forces out into the open a dirty little secret of "incremental progress" dogma: that almost twice as many American state-level jurisdictions currently recognise the existence of transsexualism as ever have established sexual orientation-based employment antidiscrimination protection: 25 to 14 ; and, the ratio of the former to states that fully

rejects older anti-transsexual federal case law, it nevertheless leans on sex stereotyping rather than transsexualism in its own right.

13 Sarah Huntley, 'A Life's Secret Unfolds - City Pays \$55,000 For Disclosure, But Damage is Done', Rocky Mountain News (Denver), 13 July 2002.

${ }^{14}$ Sweet v Mulberry Lutheran Home, NO. IP02-0320-C-H/K, 2003 U.S. Dist. LEXIS 11373 (SD Ind 6 June 2003); Oiler v Winn-Dixie Louisiana, Inc., No. 00-3114 SECTION: "I", 2002 U.S. Dist. LEXIS 17417 (ED La, 16 September 2002). Judge Posner of the Seventh Circuit also has indicated strong doubts regarding the expansiveness of Price Waterhouse v Hopkins. Hamm v Weyauwega Milk Products, Inc., $332 \mathrm{~F} 3 \mathrm{~d} 1058,1068$ ( $7^{\text {th }} \mathrm{Cir}$, 2003) ('Sex stereotyping' should not be regarded as a form of sex discrimination, though it will sometimes, as in the Hopkins case, be evidence of sex discrimination.') (Posner J concurring).

${ }^{15}$ If it is not obvious by now, in this article I will be dealing almost exclusively with American law. Progress has been far more evident in both the UK and Australia. P v S and Cornwall County Council, [1997] 2 FCR 180; Sheffield v Air Foyle Charter Airlines, No. 1200389/97 (Industrial Tribunal, 29 May 1998); Menzies $v$ Waycott [2001] VCAT 415.

${ }^{16}$ See generally Joe Crea, 'ENDA Debate Overlooks Title VII Trans Benefits: Experts; HRC, Activists Say That Trans ENDA Helps Gays', Washington Blade, 24 September 2004,

<http://www.washblade.com/ 2004/9-24/news/national/enda.cfm>; see also Stephen Clark, 'HRC Has Trans Issue Backward', Washington Blade, 20 August 2004, <http://www. washblade.com/ 2004/820/view/letters/letters.cfm>.

${ }^{17}$ If fully recognised in all possible jurisdictions, it would vastly increase employment outlook of transgendered people. 
recognise gay relationships via statute $e^{18}$ is $25^{19}$ to 0 , not a ratio at all (though it would be 25 to 1 if one takes Vermont Civil Unions ${ }^{20}$ into consideration.)

At the outset as well I must acknowledge that this article is limited almost exclusively to American law and American GLBT socio-political life. Though problems persist in both Australia and the UK (and elsewhere), the recent passage of the latter's Gender Recognition Act, ${ }^{21}$ and the direct influence of religionist zealots on government being far less in both, it is legitimate to say that the position of transsexuals is far better in Australia and the UK than in the US. And, I realise that any analysis regarding any potential applicability of Australia's new anti-same-sex marriage statute ${ }^{22}$ to transsexuals likely will not work the same as American state (or federal) statutory interaction. Nevertheless, I must note that, though I did not follow the Australian debate closely, the research I have done indicates that the plain language of the measure does not directly address recent Australian prorecognition decisions ${ }^{23}$ and does not address the effect of birth certificate statutes either from Australian states ${ }^{24}$ or American states or, for that matter, the new UK. G.R.A. Consequently, and despite it being beyond the scope of this article, it is my position that the new Australian anti-marriage statute does not impugn any rights of transsexuals.

Part II of this article looks at how a pre-1964 American federal statute addressing legal recognition of transsexuals' gender transition could have laid sufficient groundwork for courts to accept that Title VII's concept of 'because of sex' encompasses 'because of change of sex.' Part III looks at the 1968 Louisiana transsexual birth certificate statute - and certain aspects of its apparently-long-forgotten legislative history. Part IV is a look at one particular divisive aspect of Louisiana's legal landscape of today: its recently-approved anti-gay-marriage constitutional amendment. In Part V, I detail my assertion that the narrow view of Title VII espoused by some federal courts should have a functional flip side in state-level sex discrimina-

\footnotetext{
${ }^{18}$ Here I purposely do not include Massachusetts because it arose from a court decision that, at the very least, may be overturned by a state constitutional amendment and may ultimately fall to a federal amendment. See In re Opinions of the Justices to the Senate, 802 NE 2d 565 (Mass, 2004); and, Goodridge $v$ Department of Health, 798 NE 2d 941 (Mass, 2003).

19 Alyson Dodi Meiselman, Katrina C Rose and Phyllis Randolph Frye, 'Cause of Action For Legal Change of Gender', 24 CAUSES OF ACTION 2d 135 (2004).

2000 VT. LAWS Ch. 91.

${ }^{21}$ Gender Recognition Act 2004 (UK).

${ }^{22}$ Marriage Legislation Amendment Act 2004 (Cth).

${ }^{23}$ Compare Attorney-General v Kevin and Jennifer [2003] 30 FLR 1 (en banc); and Secretary, Department of Social Security v S.R.A. (1993) 118 ALR 467; with In re the Marriage of $C$ \& $D$ (falsely called C) (1979) 28 ALR 524. Beyond this is the actual text, which reads in pertinent part that 'marriage means the union of a man and a woman to the exclusion of all others, voluntarily entered into for life' and

A union solemnised in a foreign country between:

(a) a man and another man; or

(b) a woman and another woman;

must not be recognised as a marriage in Australia.

Marriage Legislation Amendment Act, 2004, schedule 1 (1) and 1 (3) (Cth).

${ }^{24}$ For example, see Sexual Reassignment Act 1988 (SA).
} 
tion law - a flip side of which transsexuals, and perhaps all transgendered people, should be able to avail themselves but, as yet, apparently have not. Part VI is a brief look at what may be the reason that the legal theory analysed in Part V has never been championed by the most influential of gay politicos that such a legal theory would require acknowledgement and acceptance of the reality of change of sex.

\section{B The Temperament}

The italicised quote at the beginning of this article, from a 1984 episode of Saturday Night Live hosted by the notorious insult comedian Don Rickles, may seem odd even offensive - as an opening for an article in favour of equality (and, even for an SNL monologue of two decades past.) Yet, it can be strongly likened to the historically cavalier attitude behind declarations by American gays and lesbians regarding what are acceptable and unacceptable strategies are for securing basic civil rights for transgendered people: when these strategies fail, it is not the gay and lesbian advocates of them who are adversely affected.

I make policy that might negatively affect transsexual people, and why not? Because I'm not one.

Is there any real difference? ${ }^{25}$

The continuing insistence on adherence to policies - both ostensibly gay-only (such as pushing for same-sex marriage despite the obviousness of the strength of the opposition to it $)^{26}$ and those directly, or even indirectly, affecting transgendered people - that are not simply failures but that actually inspire backlashes which negatively affect the transgendered to a far greater degree than against gays, lesbians and bisexuals are the embodiment of this mindset. The failure of these gay policies simply leaves gays in the position they were before, but not any worse off. ${ }^{27}$ Transsexuals, however, actually have had existing rights (or at least those which have been logically assumed to exist) taken away. ${ }^{28}$ My hope is for this article, in

\footnotetext{
${ }^{25}$ And, for those uncomfortable with utilising Don Rickles as a politico-legal analogy, I offer historian Eugene D. Genovese's assessment of racial relations: 'Wherever racial subordination exists, racism exists...' Eugene D Genovese, Roll, Jordan, Roll - The World the Slaves Made (1974) 4. Wherever subordination of transgendered people's interests exists, transphobia exists.

${ }^{26}$ Katrina C Rose, 'An Open Letter to Scott Hedin (Part Three)', Texas Triangle, 30 March 2001,

<http://www.txtriangle.com/archive/925/vpkatrose.htm> (last visited 14 September 2004).

${ }^{27}$ Though beyond the scope of this article, I feel I must make it clear that I do realise that even this is beginning to change. It is debatable whether any of the Canadian gay marriages constitute anything which an American gay couple can truly claim to have 'lost.' A recent bankruptcy decision may, or may not, provide a test for whether this could be true. In re Kandu, No. 03-51312 (WD Wash, 17 August 2004). However, a number of anti-gay-marriage backlash statutes and constitutional amendments are being drawn broadly enough so as to inspire worry that they may wipe out non-marital domestic partnership rights. NEW ORLEANS, LOUISIANA, CODE OF ORDINANCES $§ 87-1$..

${ }^{28}$ See generally the marriage decisions: Kantaras $v$ Kantaras, No. 2D03-1377, 2004 Fla. App, LEXIS 10997 (Fla Ct App, 23 July 2004); In re Nash and Barr, Nos. 2002-T-0149 \& 2002-T-0179, 2003 WL 23097095 (Ohio Ct App, 31 December 2003); In re Gardiner, 42 P3d 120 (Kan, 2002), cert. denied sub
} 
addition to helping transsexuals in many jurisdictions to gain access to the courts to combat employment discrimination, is that it will inspire thoughtful analysis of what advocates of "incremental progress" actually are hoping to see become of transgender political, social and legal viability.

And, once the real problems are identified, and once the real historical backdrop against which they lay is clarified, then the real solutions can be formulated and actually implemented - hopefully by GLBT rights organisations whose staffs truly reflect the transgender-inclusive nature of the community of persecuted sexual minorities. $^{29}$

\section{The Tale of titan $V$ Lose-Union AND the RAMifications OF the 1949 Federal Gender TRANSITION RECOGNITION ACT}

A full understanding of transgender law requires an examination not simply of applicable law, but also the history that influenced how the law came into being and the Federal Gender Transition Recognition Act ('FGTRA') needs to be fully understood to be appreciated.

Following the 1948 national elections - featuring President Harry Truman's unlikely victory over Republican Thomas Dewey, States' Rightist Strom Thurmond and progressive Henry Wallace ${ }^{30}$ - several United States House and Senate members decompressed ${ }^{31}$ by taking a ski vacation to Switzerland. While there, one among them - one who happened to be a lawyer - heard of an interesting decision that had been handed down by a Swiss Cantonal Court a few years earlier, In re Leber. $^{32}$ The decision recognised the concept of legal change of sex status for a

nom, Gardiner v Gardiner, 537 US 825 (2002); and Littleton v Prange, 9 S.W.3d 223, 225 (Tex. App. San Antonio 1999, pet. denied), cert. denied, 531 US 872 (2000).

${ }^{29}$ Donna Cartwright, 'Turning HRC's Promise Into Action', Gay City News, 2 September 2004, <http://www.gaycitynews.com/gcn_336/turninghrcspromise.html> (last visited 14 September 2004) (imploring HRC to 'hire transgender-identified people as soon as possible for prominent, visible staff positions, preferably those that involve regular contact with legislators' something the organisation has a long history of not doing).

30 'Electoral Votes for President and Vice President 1941-1953', <http://www.archives.gov/ federal_register/electoral_college/votes/1941_1953.html\#1948> (last visited 24 September 2004).

${ }^{31}$ Probably not a phrase in wide use at the time, but descriptive nevertheless.

32 And this decision relied on precedent that was even then almost fifteen years old, a decision not afforded the formality of a case citation, but which could appear to be properly referred to as In re Businger, the case of Margrith (nee Niklaus) Businger whose petition was granted by the Council of State of the Canton of Nidwald on 19 October 1931. Eugene de Savitsch, Homosexuality, Transvestism and Change of Sex (1958) 101-102 (English translation of the In re Leber opinion.) The Leber court noted that Businger

suffered from a feminine psyche, which influenced his entire behaviour. He had a predilection for female activities and, obeying irresistible impulses, dressed himself as a woman whenever possible: he was ill at ease in masculine garments and considered the obligation to wear them both disagreeable and coercive. From the physical point of view there was noth- 
person who undergoes medical treatment for what was then referred to as inversion but has in the years since come to be referred to as transsexualism. ${ }^{33}$

One of that group of Americans was a physician, and sought out the medical experts who were involved in the Leber case and an informal, yet informative, meeting resulted. Once back in America, the members of Congress who had been enlightened about In re Leber proposed that Congress enact legislation to deal positively with this sort of situation. It was viewed as necessary recognition of a medical condition by an entity that keeps records and the necessity of that entity, and all lower government entities, to be consistent in how they statistically categorise individuals according to sex. It was not seen as a civil rights measure as, in that era, civil rights proposals were D.O.A. in Congress. ${ }^{34}$ It was viewed purely as a medical matter, not as a moral issue or a civil rights agenda item, and it passed easily, without any rancour and with a bare minimum of debate evident from the Congressional Record, and was unceremoniously signed into law by President Harry Truman along with a number of other bills.

Fifteen years later, during the Lyndon Johnson administration, upfront civil rights bills fared a bit better and, in 1964, a comprehensive Civil Rights Act was enacted ${ }^{35}$ which outlawed (among other things) discrimination in employment based on race, religion and, thanks to a last-minute amendment that received precious little debate, sex. $^{36}$ That same year, Patricia Titan, a male-to-female transsexual from the small town of Rosedale, Louisiana, underwent sex reassignment surgery in Los Angeles, completing her transition from male to female.

Eventually, Patricia moved back to Louisiana, but not to her birthplace. Instead, she settled in the state capitol of Baton Rouge. In 1975, the same year that the first attempt was made to enact a federal gay rights law, ${ }^{37}$ she secured a secretarial position at the Baton Rouge headquarters of the regional grocery store chain LoseUnion. After ten years with the company, during which time she had received several promotions, raises and commendations, her supervisor learned of her transsexual history.

ing feminine about Businger. He had normal masculine genital organs, but he held them in such abhorrence that he attempted self-mutilation. It was to prevent this that the surgeon deemed it necessary to castrate him. Here we are dealing with a human being who, while possessing male genitalia, had in his psychological constitution cells which functioned in two ways, some in a masculine way and others in a feminine way. Psychically he was more woman than man, but physically he was a combination of man and woman. His desire to change his civic status and name was so strong that he threatened to commit suicide unless his wish was granted.

Ibid 101 (summarising the facts of Businger's case).

${ }^{33}$ The term was coined by David O. Cauldwell but was later popularised by Harry Benjamin. Joanne Meyerowitz, How Sex Changed - A History of Transsexuality in the United States (2002) 15.

${ }^{34}$ See generally Robert Mann, The Walls of Jericho (1996).

${ }^{35}$ Act of 2 July 1964, PL 88-352, 78 Stat 253.

${ }^{36}$ See Robert Stevens Miller Jr., 'Sex Discrimination and Title VII of the Civil Rights Act of 1964', (1967) 51 Minnesota Law Review 877, 879-84.

${ }^{37}$ H.R. $166,94^{\text {th }}$ Cong. $1^{\text {st }}$ Sess. (1975). 
She was fired the next day, with the company specifically stating that she was being fired because she is a transsexual and that the presence of a transsexual on the company's payroll would conflict with the company's mission to operate according to Christian principles. The termination letter even quoted verses from Leviticus and Deuteronomy. ${ }^{38}$

Patricia brought a claim under Title VII of the 1964 Civil Rights Act, alleging discrimination in employment because of sex and because of religion. The attorneys for Lose-Union argued that Congress had had numerous opportunities to amend Title VII to include sexual orientation or sexual preference but had not done so (and even listed all of the proposals to do just that, proposals which had begin to be introduced in 1975), which meant that it would be judicial legislation to hold that an action for anti-transsexual discrimination was cognisable under Title VII. Patricia's attorneys, however, argued that the company's action against her was taken for no other reason than because she used to be male, though it was couched in terms of religionist oppression. Analogising that, per the statute's prohibition against discrimination based on religion, it was inconceivable that the company would be allowed to fire her if it had discovered that she used to be a Christian but was now an adherent to Judaism, there was no rational reason that the same principle should not apply to 'sex.'

To this the company's legal team replied, making note of that lack of debate over the addition of 'sex' to the Civil Rights Act, ${ }^{39}$ that Congress simply did not have the concept of 'because of change of sex' in mind when it enacted legislation outlawing discrimination 'because of sex.' Patricia's attorneys, though, noted that Congress had enacted the FGTRA a decade and a half prior to Title VII, meaning that, although it may not have been (in fact, unquestionably was not) front-and-centre during debate in 1964, Congress indeed did have a history of encompassing the concept of 'change of sex' when legislating on the subject of 'sex.'

Noting the sex slate upon which Title VII was written by virtue of the existence of the FGTRA, the federal district court not only denied Lose-Union's motion for summary judgment but granted Patricia's. The company appealed to the Fifth Circuit Court of Appeals, which in 1988 upheld the judgment in favour of Patricia by issuing a short, terse opinion, favourably citing the following passage from In re Ladrach, an Ohio Probate Court opinion issued the year prior denying a marriage license to a post-operative male-to-female transsexual but with the caveat:

It seems obvious to the court that if a state permits such a change of sex on the birth certificate of a post-operative transsexual, either by statute or administrative ruling, then a marriage license, if requested, must issue to such a person provided all other statutory requirements are fulfilled. ${ }^{40}$

\footnotetext{
${ }^{38}$ Leviticus 18: 22; Deuteronomy 22:5.

${ }^{39}$ See Miller, above n 36.

${ }^{40}$ In re Ladrach, 513 NE 2d 828, 831 (Ohio Prob Ct, Stark County, 1987) (emphasis added).
} 
The federal appellate court surmised that the same rationale applied to Titan $v$ LoseUnion - indeed, to any case involving a transsexual seeking redress under Title VII for discrimination because of change of sex: while Title VII may not have said 'because of change of sex,' it would be disingenuous not to apply Congress' history of acknowledging the concept of 'change of sex' to usage of the word "sex" by itself.

Lose-Union petitioned the U.S. Supreme Court to hear the case, but the request was denied, leaving the FGTRA and Patricia Titan's Title VII triumph to stand as remarkably positive and enlightened developments in the area of transgender law.

This was indeed a watershed moment in the history of transsexuals in America. No longer could employers robotically force transsexuals out of the legitimate labour force and into the sex industry. Anyone fired because of being transsexual (or suspected of being so) would have a right of redress to their government.

Of course, there is just one problem concerning Titan $v$ Lose-Union and the FGTRA, a problem of which legal practitioners absolutely must be aware.

They never happened. ${ }^{41}$

\section{1968 LOUISIANA ACt No. 611}

However much of Part II may seem like a cruel joke, ${ }^{42}$ please rest assured that, despite the fictional aspects of it, it was not intended as such. More importantly, however fantastic portions of this Part may seem, rest assured to an equal degree that none of it is fictional.

\section{A 1968 (In and of Itself)}

In conducting the research that would eventually become part of this article, I reviewed microfilm of the Baton Rouge, Louisiana, Morning Advocate from the summer of 1968. In doing so, I was reminded of just how turbulent those times were. I hadn't initially zeroed in on the dates on which the legislative activity took

\footnotetext{
${ }^{41}$ Almost forgotten is that Arlette Leber and her court case (as well as In re Businger, the 1931 case cited therein as then-existing precedent) did happen - along with the other real cases, laws and proposals cited in the recount of Titan v Lose-Union. Notably, twelve years after Ms. Leber's legal gender transition, Dr. Otto Riggenbach, concluded an evaluation of her with the following statement: "The operation, on the one part, combined with the permission of the authorities to change her civic status, on the other, has turned an unstable and unhappy individual into a useful and contented member of society." De Savitsch, above $\mathrm{n} 32$

${ }^{42}$ Purists should note that in the introduction I speak of how the pre-1964 statute could have laid the groundwork for employment anti-discrimination protection, not that it did.
} 
place (because I didn't know which dates those were), so, assuming (wrongly as I will detail below) that the bill might have slipped under the radar I looked at issues from early June - in which there was ample coverage of the ongoing Viet Nam War, ${ }^{43}$ the assassinations of Sen. Robert Kennedy and Martin Luther King, ${ }^{44}$ and even events related to as-yet-unresolved conspiracy theories regarding an assassination several years prior. ${ }^{45}$

Also, at this point, the entire Louisiana Legislature had only one African-American member, future New Orleans Mayor Ernest Morial, who then was in his first term as the first African-American member of the Louisiana Legislature since the postCivil War Reconstruction era of the nineteenth century. ${ }^{46}$ Moreover, in looking at all issues of the Morning Advocate from May through July of 1968, one can find any number of blatantly race-specific want-ads. ${ }^{47}$

Nevertheless, it was during this era - with a law-and-order governor who viewed desecration of the U.S. flag as 'disloyalty, which is a polite way of saying treason' 48 - that the Louisiana Legislature addressed the issue of transsexualism.

A recipe for disaster for transsexuals?

Surprisingly, not.

\section{B Act No. 611}

One of my assumptions about Louisiana's 1968 birth certificate statute long had been that it had come into being solely at the behest of Reed Erickson, a wealthy female-to-male transsexual from Baton Rouge who founded (and funded) the Erickson Educational Foundation (EEF), one of the earliest American transgender resource outlets. ${ }^{49}$ Upon coming across what must be regarded, despite its brevity, as an extremely persuasive piece of the statute's legislative history, I realised that I apparently had been mistaken. ${ }^{50}$

\footnotetext{
${ }^{43}$ See generally, 'American Planes Blast N. Viets Near Da Nang', Morning Advocate (Baton Rouge, La.), 18 May 1968, 1.

44 'King Murder Suspect is Arrested in London', Morning Advocate (Baton Rouge, La.), 9 June 1968, 1A; 'RFK Will be Buried in Arlington Today', Morning Advocate (Baton Rouge, La.), 6 June 1968, 1-A.

${ }^{45}$ Compare 'Officer Claims Shaw Gave as Alias "Clay Bertrand," Morning Advocate (Baton Rouge, La.), 27 July 1968, 20-A; with JFK (Warner Bros. 1991).

46 'State's First Negro Legislator Says He's “Angry Young Man”, Morning Advocate (Baton Rouge, La.), 12 May 1968, 14-A.

${ }^{47}$ Just one of many, a sales collection position had the bold heading "Colored Women." Morning Advocate (Baton Rouge, La.), 12 June 1968, Sec. C. And, 1968 was less than a decade after the Legislature, spurred by court decisions, repealed mandatory school racial segregation provisions. 17 LA. REV STAT. $\$ 331$, et. seq., repealed, 1960 ( $1^{\text {st }}$ Ex. Sess. $)$ LA. ACTS Ch. 9.

${ }^{48}$ Compare, 'Governor Asks Punishment For Those Who Break Law', Morning Advocate (Baton Rouge, La.), 9 May 1968, 7-F; with, Texas v Johnson, 491 US 397 (1989).

${ }^{49}$ Holly Devor, 'Reed Erickson and The Erickson Educational Foundation', <http://web.uvic.ca/ erick123/> (last visited 23 September 2004).

${ }^{50}$ Even so, I would not be surprised to learn that the EEF conferred as to language specifics of the proposal.
} 
In an article on the birth certificate bill in the June $28^{\text {th }}$ edition of the Morning Advocate, it was noted: 'Sponsors explained that the birth certificate change is needed by a woman, formerly a man, who desires to get married. ${ }^{51}$ Quite obviously then, the bill was spurred by the predicament of a male-to-female transsexual, not a female-to-male - Erickson or any other. And, if a news item from earlier in the session is any indication, ${ }^{52}$ the woman in question was Debra Majeau, whose effort to secure transition recognition was mentioned in Douglas K. Smith's stillinfluential 1971 Cornell Law Review article on transsexualism and the law, ${ }^{53}$ (though without any indication of her apparent role in getting the law enacted.) Perhaps more significantly, however, the above-quoted sentence clearly indicates that the intended effect of the bill would be to allow those who transition to be regarded for purposes of marriage as members of their post-transition sex.

The House debate on the bill appears to have been replete with a significant amount of commentary, evidently intended as humorous, that probably would be regarded today as either politically incorrect or downright offensive. Rep. William Boyd of Lake Charles even "chided his colleagues for not considering the bill seriously. ${ }^{, 54}$ Rep. Chris Faser had gone so far as to introduce what was characterised as a "gag" amendment to the bill: "The provisions of this bill shall not apply to Rep. Speedy Boudreaux of Baton Rouge. ${ }^{, 55}$ Even one of the bill's sponsors, freshman Rep. John J. Hainkel of New Orleans, remarked: 'I just want to announce that Jesuit High School now has its first female graduate. ${ }^{56}$

To reiterate, I'm sure that much of what was said on the floor of the Louisiana House of Representatives that day might now be regarded as offensive. But, the quote from Rep. Hainkel should give one an idea of what the outcome was as to the pertinent issue, namely the bill that was under consideration. He was sincerely referring to a bill serious that had passed.

According to one article it had passed the House unanimously, though another listed the vote tally as 87-8 - still an overwhelming endorsement. ${ }^{57}$ And, it went on to be passed by the Senate - unanimously - and approved by Gov John McKeithen, ${ }^{58}$

\footnotetext{
51 'Mirthful Exchanges Accompany House Sex-Switch Bill Okay', Morning Advocate (Baton Rouge, La.), 28 June 1968, 17-A (emphasis added).

52 "'He's a "She", But Records Not Changed, Morning Advocate (Baton Rouge, La.), 4 May 1968, 8-B.

${ }^{53}$ Douglas K Smith, 'Transsexualism, Sex Reassignment Surgery, and the Law' (1971) 56 Cornell Law Review 963.

54 'Mirthful Exchanges', above n 51, 17-A.

${ }^{55}$ Ibid.

${ }^{56}$ Ibid. This actually should not necessarily be viewed as offensive; more than a few MTFs who attended all-male institutions pre-transition have made similar comments about themselves.

57 'Mirthful Exchanges', above n 51, 17-A; 'Louisiana Legislative Digest', Morning Advocate (Baton Rouge, La.), 28 June 1968, 16-A (noting the 87-8 tally).

581968 LA. ACTS Ch. 611; 'Louisiana Legislative Digest', Morning Advocate (Baton Rouge, La.), 7 July 1968, 16-A (noting the Senate vote of 38-0); and 'List Bills Signed, Constitutional Amendments', Morning Advocate (Baton Rouge, La.), 27 July 1968, 13-A, 15-A (noting the governor's signing of H.B. 1224).
} 
removing any question as to whether the law and public policy of Louisiana recognises the medico-legal concept of transsexualism. ${ }^{59}$ Neither the Legislature nor Louisiana's courts have ever seen fit to eliminate the state's sodomy statute, however. $^{60}$ And, in 1999, the state even enacted a state anti-gay marriage statute. ${ }^{61}$ Unanimously. ${ }^{62}$

\section{The Other Birth Certificate Statutes}

Now, as eager as one might be to assume that the 1968 Louisiana statute simply must have been the first transsexual birth certificate statute, ${ }^{63}$ it was not; nor was it even the second. By June of 1968, there were already two such statutes in force. Arizona's had been enacted the previous year ${ }^{64}$ and Illinois enacted its statute in 1961. ${ }^{65}$ As of 2004, approximately half of the state-level jurisdictions in the United States have such statutes, meaning (and this is the important concept for transsexuals to grasp) that this half of America's jurisdictions have, via their elected representatives, recognised the medical reality of transsexualism and recognised it in law as a positive element of their public policy.

Those two words are critical.

They are increasingly being incorporated into anti-gay marriage statutes in an effort to insulate them from honest 'full faith and credit' analysis pursuant to Article IV of the U.S. Constitution. Significantly, pro-transsexual public policy exists in more than just those three states - even where there is clear anti-gay public policy (purported public policy at least.)

\footnotetext{
59 The statute:

Any person born in Louisiana who has sustained sex reassignment or corrective surgery which has changed the anatomical structure of the sex of the individual to that of a sex other than that which appears on the original birth certificate of the individual, may petition a court of competent jurisdiction as provided in this Section to obtain a new certificate of birth. is still in effect and is codified at: LA. REV. STAT. $§ 40: 62$ (A) (2004).

${ }^{60}$ State v Smith, 766 So 2d 501 (La, 2000).

${ }^{61} 1999$ LA. ACTS. Ch. 890.

62 1999 LA. H.B. 1450 (final House vote: 95-0, with 8 absent; final Senate vote: 32-0, with 7 absent).

${ }^{63}$ In fact, several years ago and before I began doing extensive research into all of the state transsexual statutes, I asserted as much at a Panel at the National Lesbian-Gay Law Association Conference in Dallas. Knowledge is good. More knowledge is better - if it is reasonably accurate.

${ }^{64} 1967$ ARIZ. LAWS Ch. 77, § 2. This was shortly before future US Supreme Court Justice Sandra Day O'Connor became a member of the Arizona Senate, so, unfortunately, the vote tally from this does not offer any direct insight into how she might deal with transsexuals' identity and marital rights when they finally do make it to the high court. She did, however, cast a vote in 1973 for a bill that added language to an adjoining section of the vital statistics act, so she should be presumed to have at least cast her eyes near the language of a transsexual birth certificate statute. See 1973 ARIZ. LAWS Ch. 51; and 1973 Arizona Senate Journal 301 (14 March 1973).

${ }^{65} 1961$ ILL. LAWS p. $2935 \S 17$. Notably, although the governor who signed this provision into law was a Democrat, both houses of the legislature that passed the measure were controlled by the Republicans. 'Senate Organizes', Illinois Legislative Bulletin, 4 January 1961, 1; 'House Action', Illinois Legislative Bulletin, 4 January 1961, 1.
} 


\begin{tabular}{|c|c|c|c|}
\hline Jurisdiction & $\begin{array}{l}\text { Year of Enactment of } \\
\text { Statute Recognising } \\
\text { Transsexualism }\end{array}$ & $\begin{array}{l}\text { Year of Enactment of } \\
\text { Statute Attacking the } \\
\text { Concept of Gay } \\
\text { Marriage }\end{array}$ & $\begin{array}{l}\text { Any Evidence of Any Connection } \\
\text { Between the Two so as to Equate } \\
\text { Public Policy Against Gay Mar- } \\
\text { riage With a Public Policy Against } \\
\text { Transsexuals? }\end{array}$ \\
\hline Alabama & $\begin{array}{l}1992 \\
(1992 \text { Ala. Acts No. } \\
92-607, \S 19)\end{array}$ & 1998 & $\dagger$ \\
\hline Arkansas & $\begin{array}{l}1981 \\
(1981 \text { Ark. Acts No. } \\
120, \S 12)\end{array}$ & 1997 / 2004 & $\begin{array}{l}\text { 1981: My review of the Arkansas } \\
\text { Democrat from the time of the } \\
\text { birth certificate enactment indicates } \\
\text { no coverage of the bill. } \\
\text { 2004: Transsexuals' rights absent } \\
\text { from discourse on anti-same-sex- } \\
\text { marriage ballot measure. }\end{array}$ \\
\hline Arizona & $\begin{array}{l}1967 \\
(1967 \text { Ariz. Laws Ch. } \\
77, \S 2)\end{array}$ & 1996 & $\dagger$ \\
\hline California & $\begin{array}{l}1977 \\
\text { (1977 Cal. Laws Ch. } \\
1087)\end{array}$ & $1977 / 2000$ & $\begin{array}{l}\text { 1977: Concept raised, but trans- } \\
\text { sexuals' marital rights not deni- } \\
\text { grated by the plain language of the } \\
\text { anti-gay bill or the subsequent } \\
\text { transsexual birth certificate bill. } \\
\text { 1997: Gender transition recognised } \\
\text { at trial court level in Vecchione } v \\
\text { Vecchione divorce action; no } \\
\text { appellate or legislative response } \\
\text { against it. } \\
\text { 2000: Transsexuals' rights totally } \\
\text { absent from Prop. } 22 \text { discourse. } \\
\text { 2004: Current discourse regarding } \\
\text { San Francisco gay marriages is } \\
\text { totally devoid of any mention of } \\
\text { heterosexual marriages involving } \\
\text { transsexuals. }\end{array}$ \\
\hline Colorado & $\begin{array}{l}1984 \\
(1984 \text { Colo. Laws } \\
\text { Ch. 206) }\end{array}$ & 2000 & See infra, Part IV, C, 2 \\
\hline Connecticut & $1975^{*} / 2001^{*}$ & none & $\dagger$ \\
\hline
\end{tabular}

\footnotetext{
* The non-transsexual-specific birth certificate statutes in Connecticut and Puerto Rico were held by court decision to be inclusive of transsexuals' identity rights. Darnell v Lloyd, 395 F Supp. 1210 (D Conn, 1975); Ex Parte Torres, 2000 JTS 120, 2000 TSPR 109 (PR, 2000). The decisions have never been overturned by statute or subsequent court decision. Moreover, Connecticut has since amended its
} 


\begin{tabular}{|c|c|c|c|}
\hline D.C. & $\begin{array}{l}1981 \\
\text { (1981 D.C. Laws No. } \\
4-34, \S 18)\end{array}$ & $\begin{array}{l}\text { none / } 1996 \\
\text { (Federal DOMA) }\end{array}$ & $\dagger$ \\
\hline Georgia & $\begin{array}{l}1982 \\
(1982 \text { Ga. Acts No. } \\
1216, \S 1)\end{array}$ & $1996 / 2004$ & $\begin{array}{l}\text { 2004: Transsexuals' rights absent } \\
\text { from discourse on anti-same-sex- } \\
\text { marriage ballot measure. }\end{array}$ \\
\hline Guam & $\begin{array}{l}\text { (I have been un-able } \\
\text { to ascertain when the } \\
\text { Guam statute was } \\
\text { enacted.) }\end{array}$ & $\begin{array}{l}\text { none / } 1996 \\
\text { (Federal DOMA) }\end{array}$ & $\dagger$ \\
\hline Hawaii & $\begin{array}{l}1973 \\
\text { (1973 Haw. Acts No. } \\
\text { 39) }\end{array}$ & 1998 & $\begin{array}{l}\text { 1993-1998: Baehr litigation and its } \\
\text { aftermath totally devoid of any } \\
\text { reference to marital rights of trans- } \\
\text { sexuals. }\end{array}$ \\
\hline Illinois & $\begin{array}{l}1961 \\
(1961 \quad \text { Ill. Laws p. } \\
2935, \S 17)\end{array}$ & 1996 & $\begin{array}{l}\text { 1978: Penumbral reading of the } \\
1961 \text { statute in City of Chicago v } \\
\text { Wilson, but question of transsexu- } \\
\text { als' marital rights not discussed. }\end{array}$ \\
\hline Iowa & $\begin{array}{l}1976 \\
\text { (1976 Iowa Laws Ch. } \\
\text { 1111) }\end{array}$ & 1998 & $\begin{array}{l}\text { 1976: No press coverage of the } \\
\text { birth certificate statute. } \\
\text { 1978-80: No mention of marital } \\
\text { rights during Pinneke } v \text { Preisser } \\
\text { SRS funding litigation. } \\
\text { 1998: Amendment introduced } \\
\text { during DOMA battle, but no plain } \\
\text { language in statute denigrating } \\
\text { rights flowing from the } 1976 \text { birth } \\
\text { certificate statute. }\end{array}$ \\
\hline Kentucky & $\begin{array}{l}1990 \\
(1990 \text { Ky. Acts Ch. } \\
369, \S 23)\end{array}$ & $1998 / 2004$ & $\dagger$ \\
\hline Louisiana & $\begin{array}{l}1968 \\
\text { (1968 La. Acts. Ch. } \\
611)\end{array}$ & $1999 / 2004$ & See infra Part III, B \\
\hline Maryland & 1995 & 1973 & 2003: State high court dodges the \\
\hline
\end{tabular}

vital statistics statutory framework to address "gender change," 2001 CONN. ACTS Ch. 01-163, § 32; after briefly having a statute only addressing only gender changes related to "hermaphroditism." 1997 (18 June Sp. Sess.) CONN. ACTS. 97-10, § 3; 1997 (18 June Sp. Sess.) CONN. ACTS. 97-8, § 44.

The then-non-transsexual-specific birth certificate statute in Massachusetts was construed in an attorney general's opinion to be inclusive of transsexuals' identity rights. 1975 Mass. AG Op 62. It was amended to be transsexual-specific in 1981 (the year after long-time opponent of including the transgendered in federal employment antidiscrimination legislation Barney Frank left the Massachusetts legislature to go to Congress.) 1981 MASS. ACTS. Ch. 684. 


\begin{tabular}{|c|c|c|c|}
\hline & $\begin{array}{l}\text { (1995 Md. Laws Ch. } \\
\text { 97) }\end{array}$ & & issue in In re Heilig. \\
\hline Massachusetts & $\begin{array}{l}\text { 1975*/ } 1981 \\
\text { (1981 Mass. Acts Ch. } \\
684)\end{array}$ & none & $\begin{array}{l}\text { 1975: Pre-statutory pro-transsexual } \\
\text { Attorney General's opinion in- } \\
\text { cludes no marital limitation } \\
\text { 2001-2004: Goodridge litigation } \\
\text { completely devoid of any reference } \\
\text { to marital rights of transsexuals. }\end{array}$ \\
\hline Michigan & $\begin{array}{l}1978 \\
(1978 \quad \text { Mich. Pub. } \\
\text { Acts No. 368) }\end{array}$ & $1996 / 2004$ & $\dagger$ \\
\hline Missouri & $\begin{array}{l}1984 \\
\text { (1984 Mo. Laws S.B. } \\
\text { 574) }\end{array}$ & $1996^{* * * *} / 2001 / 2004$ & $\dagger$ \\
\hline Nebraska & 1994 & 2000 & $\begin{array}{l}\text { 2000: Discourse regarding the anti- } \\
\text { gay-marriage Initiative } 416 \text { appears } \\
\text { to have totally ignored the issue of } \\
\text { marital rights of transsexuals. }\end{array}$ \\
\hline New Mexico & $\begin{array}{l}1981 \\
(1981 \text { N.M. Laws Ch. } \\
\text { 309, §19) }\end{array}$ & none & $\dagger$ \\
\hline New Jersey & $\begin{array}{l}1976^{* *} / 1984 \\
(1984 \text { N.J. Laws Ch. } \\
191)\end{array}$ & none & $\begin{array}{l}\text { 1976: No indication of any popular } \\
\text { link between the issue of gay } \\
\text { marriage and the recognition of } \\
\text { gender transition in M.T. } v J . T \text {; } \\
\text { news coverage is scant, but re- } \\
\text { spectful; the decision is viewed as } \\
\text { recognition of the reality of sex, } \\
\text { not a threat to the institution of } \\
\text { marriage. } \\
\text { 2001-present: Ongoing gay mar- } \\
\text { riage litigation attacks the aspect of }\end{array}$ \\
\hline
\end{tabular}

\footnotetext{
**** The 1996 Missouri DOMA statute was declared unconstitutional for violating the anti-logrolling provision of the Missouri Constitution. St. Louis Health Care Network v State, 968 SW 2d 145 (Mo, 1998). However, there is no indication whatsoever that either enactment - or the recently-enacted constitutional amendment - had any target other than homosexual relationships.

Civil marriage in this state shall consist only of the union of one man and one woman. In this state no effect shall be given to any public act, record, or judicial proceeding of any other state, territory, or possession of the United States, Indian tribe, or foreign nation, respecting a relationship of any union other than a union of one man and one woman that is treated as a marriage under the laws of such other jurisdiction, or a right or claim arising from such a relationship.

2004 Mo. H.J.R. 39.
} 


\begin{tabular}{|c|c|c|c|}
\hline & & & $\begin{array}{l}\text { the pro-transsexual M.T. } v J . T \text {. } \\
\text { decision holding that marriage is } \\
\text { limited to opposite-sex couples. }\end{array}$ \\
\hline North Carolina & $\begin{array}{l}1975 \\
(1975 \text { N.C. Laws Ch. } \\
556)\end{array}$ & 1996 & $\dagger$ \\
\hline Oregon & $\begin{array}{l}1981 \\
(1981 \text { Or. Laws Ch. } \\
221, \S 1)\end{array}$ & 2004 & $\begin{array}{l}\text { 1998: Failed initiative, 'The Family } \\
\text { Act', would have mandated that } \\
\text { 'gender is determined at the mo- } \\
\text { ment of conception.' }\end{array}$ \\
\hline Puerto Rico & $2000^{*}$ & $\begin{array}{l}\text { none / } 1996 \\
\text { (federal DOMA) }\end{array}$ & $\dagger$ \\
\hline Utah & $\begin{array}{l}1981 \\
(1981 \text { Utah Laws Ch. } \\
126, \S 3)\end{array}$ & $1995 / 2004$ & $\begin{array}{l}\text { 2004: Transsexuals' rights absent } \\
\text { from discourse on anti-same-sex- } \\
\text { marriage ballot measure. }\end{array}$ \\
\hline Virginia & $\begin{array}{l}1979 \\
(1979 \text { Va. Acts Ch. } \\
711)\end{array}$ & 1997 & $\begin{array}{l}\text { 1979: No explicitly anti-marriage } \\
\text { language. } \\
\text { 1985-86: Attorney General's } \\
\text { opinion on the birth certificate } \\
\text { statute (1985-86 Va. A.G. Op. 182) } \\
\text { gives no indication of lack of } \\
\text { marital rights. } \\
\text { 2004: Transsexuals' rights absent } \\
\text { from discourse on broad anti-same- } \\
\text { sex statutory measure. }\end{array}$ \\
\hline Wisconsin & $\begin{array}{l}1985 \\
(1985 \text { Wis. Acts. Ch. } \\
315)\end{array}$ & none & $\begin{array}{l}\text { 1985: No hint of denigration of } \\
\text { marital rights in legislative history } \\
\text { of birth certificate statute. } \\
\text { 1997: A proposed amendment to a } \\
\text { DOMA proposal would have } \\
\text { clarified that the bill would not } \\
\text { have adversely affected heterosex- } \\
\text { ual marriages involving transsexu- } \\
\text { als. } \\
\text { 2003: Vetoed DOMA bill had no } \\
\text { language aimed at heterosexual } \\
\text { marriages involving transsexuals. }\end{array}$ \\
\hline
\end{tabular}

\footnotetext{
** Transsexuals' identity AND post-transition marital rights were recognised in 1976 by a court decision specifically upholding the concept of opposite-sex-only marriage. M.T. v J.T., 355 A2d 204 (NJ Super App Div, 1976), cert. denied, 364 A2d 1076 (1976). This decision has not only never been overturned, but a statute specifying that New Jersey-born transsexuals can correct their birth certificates to reflect post-transition reality was enacted in 1984. 1984 NJ LAWS Ch. 191.
} 
$\dagger$ Indicates that though I have not found any indication in legislative documents or published decisional law evidencing any intent to target transsexuals with DOMAs, I have yet to complete sufficient analysis of popular discourse (typically, newspaper coverage of the legislative sessions at issue) to feel comfortable offering any conclusion other than that logically mandated by the plain language of the statutes - namely, that transsexuals' post-transition marital rights are intended by the birth certificate statutes and are not negatively targeted by the anti-gay-marriage statutes.

\section{The 2004 Constitutional Amendment, et. AL.}

\section{A Louisiana}

Marriage in the state of Louisiana shall consist only of the union of one man and one woman. No official or court of the state of Louisiana shall construe this constitution or any state law to require that marriage or the legal incidents thereof be conferred upon any member of a union other than the union of one man and one woman. A legal status identical or substantially similar to that of marriage for unmarried individuals shall not be valid or recognised. No official or court of the state of Louisiana shall recognise any marriage contracted in any other jurisdiction which is not the union of one man and one woman. ${ }^{66}$

Although I will discuss a second potential effect of the public policy embodied in Louisiana's 1968 transsexual birth certificate statute in Part V, the most obvious and immediate effect of it is that transsexuals born there should face no obstacles in obtaining state recognition of their transitions and those in (or seeking to enter into) heterosexual marriages there should have no problem having those marriages recognised in Louisiana even after the enactment of the anti-same-sex marriage amendment - whose language is italicised above. The Senate sponsor of the amendment was Senator John Hainkel - the same man who, 36 years earlier, as a freshman representative, spearheaded the passage of the birth certificate statute. And, as shown earlier, it was enacted specifically in response to an MTF constituent who had been blocked from obtaining a marriage license because of the male designation on her birth certificate.

\footnotetext{
${ }^{66}$ Kevin McGill, 'Same-Sex Marriage Proposal a Wordy Proposition', The Advocate (Baton Rouge, La.), 13 September 2004 <http://2theadvocate.com/stories/091304/ opi_samesex001.shtml> (quoting the 2004 ballot proposal's language). Note: this newspaper is the same one referenced for the 1968 events; it simply no longer is referred to as the Morning Advocate. It should not be confused with the national gay newsmagazine also called The Advocate.
} 
The upshot?

Hainkel's obvious knowledge of the difference between same-sex marriage and a heterosexual marriage involving a transsexual equates to clear legislative intent from 1968 by the state of Louisiana to allow post-transition transsexuals to marry members of their pre-transition sex. This combined with the continued existence of the 1968 statute during the enactment of the state DOMA statute in 1999, the repeated assertions of legislators during debates leading up to the submission of the 2004 proposal that if enacted it would simply solidify existing law, and the absolute absence of transsexuals' rights from the discourse surrounding the measure, ${ }^{67}$ should mean that, the approval of the amendment by the voters translates to transsexuals' marital rights having been enshrined in Louisiana's Constitution. ${ }^{68}$

Of course, almost immediately, gays in Louisiana sued, initially appearing to be successful, ${ }^{69}$ to overturn the amendment (their claim is that the measure addressed more than one subject - gay marriage and domestic partnership - in contravention of the prescribed method of amending the state's constitution. ${ }^{70}$ ) Consequently, it is not inaccurate to say that gays have overturned transsexuals' constitutionallyenshrined Louisiana marital rights.

Inflammatory?

Possibly. But, objectively, can it actually be said that this any more inflammatory than the gay-dictated, top-down "incremental progress" was insulting to the transgendered?

\footnotetext{
${ }^{67}$ For example, an opinion piece prior to the election expressed the following concerns over the expansive language:

Could an elderly gay man be denied a contract granting him next-of-kin visitation rights when his longtime partner is dying in a hospital? Could an employer's decision to extend medical benefits to an employee's same-sex partner be nullified? Would the amendment affect custody rights of gays and lesbians?

McGill, above n 66. Nowhere in the piece were transsexuals mentioned.

${ }^{68}$ Although the vote was allowed to take place, there was an admonition from its Chief Justice that the proposal might be violative of the state's 'single subject' requirement for ballot measures. Doug Simpson, 'Voters Will Cast Ballots on Gay Marriage Ban', The Advocate (Baton Rouge, La.), 2 September 2004, <http://2theadvocate.com/stories/090204/new_voteongay001.shtml> (last visited 14 September 2004).

Apparently marriage was at least touched upon in 1968, but not post-transition heterosexual marriages. The Baton Rouge Morning Advocate indicated a floor amendment to the 1968 birth certificate bill "to make a person married to [a transsexual utilising the birth certificate conformation provisions of the act] a necessary [party] to the lawsuit involved." 'Louisiana Legislative Digest', above n 57.

${ }^{69}$ Louisiana Supreme Court Agrees To Hear Gay Marriage Appeal, 365gay.com, 14 October 2004 <http://www.365gay.com/newscon04/10/101404laSupreme.htm>.

${ }^{70}$ Simpson, above n 66.
} 


\section{B Before Louisiana: Congress}

In a very real sense it is impossible for a man to marry a man or a woman to marry a woman. The very meaning of the word marriage necessarily contemplates a relationship between a man and a woman. For nearly 228 years every state in the union has followed this millennia-old tradition. Not once in the history of this nation have the people, speaking through their elected representatives or otherwise, passed a single law altering this tradition in the slightest way.

$\cdots$

It goes without saying that for thousands of years of human history, until recently, marriage has, at all times and at all places, been reserved as the union between male and female. In the American experience from the beginning of the Republic until last month, there was - there has never been a same-sex marriage. Even then, it took four members of a lawless court to impose a same-sex marriage on the people. The people of Massachusetts did not seek such a law, and they do not want it. ${ }^{71}$

However much that the religionist opportunists, ${ }^{72}$ such as Colorado Representative Marilyn Musgrave (who made the statements above), who are pushing the Federal Marriage Amendment ${ }^{73}$ and the so-called Marriage Protection $\mathrm{Act}^{74}$ (intended to remove interpretation of the 1996 DOMA from the jurisdiction of the federal courts) may - or may not - desire for heterosexual transsexual marriages to be wiped out as if they were same-sex marriage when ${ }^{75}$ the amendment becomes part of the U.S. Constitution or when the statute passes (or both), they must contend with a formidable opponent: history. And, if courts interpreting either (or both) exhibit even the slightest degree of interpretational honesty, they will come to the conclusion that such marriages were not targeted by either - or by the federal DOMA which preceded them.

And, they will have to contend with statements such as Musgrave's above - and many others.

\footnotetext{
${ }^{71}$ Hearing on the Proposed Federal Marriage Amendment, U.S. Senate, Judiciary Committee (22 June 2004) (testimony of Rep. Marilyn Musgrave) (audio recording on file with author).

${ }^{72}$ And no objective look at the political landscape can yield any conclusion other than that those pushing these proposals do not care in the slightest about 'defending' marriage (whatever that might actually entail) but, instead, care deeply about electing religionist Republicans to office - particularly the office of the presidency. In fact, the biggest fight in the Louisiana Legislature in 2004 over gay marriage was not the amendment per se but whether or not the vote would be in September (as ultimately occurred) or on the day of the November general election, when the increased conservative Christian turnout for the anti-gay vote would benefit the Christian religionist incumbent president, George W Bush.

${ }^{73} 2004$ S.J. Res. $30,108^{\text {th }}$ Cong, $2^{\text {nd }}$ Sess. (22 March 2004); 2004 S.J. Res. $40,108^{\text {th }}$ Cong, $2^{\text {nd }}$ Sess. $(7$ July 2004).

${ }^{74} 2003$ H.R. 3313, $108^{\text {th }}$ Cong. $1^{\text {st }}$ Sess. (16 October 2003).

${ }^{75}$ Pessimistic as it may be, for that I must say "when", not "if."
} 


\section{$1 \quad 1996$, et. al.}

In 1996, as the DOMA proposal was approaching passage, Dana Priesing, a MTF transsexual attorney then with GenderPAC, asserted that it was 'unclear...whether Congress intended DOMA to reach back to invalidate marriages in which the spouses were of opposite sexes when the marriage was performed, but are members of the same sex now. ${ }^{76}$ The reality is that Congress appears never to have broached the subject of this specific type of same-sex marriage.

Far more significant, however, is the extent to which Congress addressed the validity under DOMA of a heterosexual marriage between two individuals who, at their respective births, were designated as being members of the same sex, though, by the time of the marriage, one of whom had undergone SRS and become recognised as a member of the sex opposite of the other person - in other words, what the average person would think of as a marriage that might involve a transsexual and what indeed is type of marriage at issue in the vast majority of cases involving 'transsexual marriages.'

The extent to which this was discussed?

Not at all.

Although 39 states now have some form of state law or constitutional provision which can be referred to as a mini-DOMA, the mother of all DOMAs is that passed by the U.S. Congress in $1996 .^{77}$ In light of the current very real possibility of DOMA's 'take' on marriage becoming part of the U.S. Constitution, it is essential that not just transsexuals but also legal practitioners and members of the judiciary (not just in America but in all nations that may refer to U.S. law) have the clearest understanding possible of precisely what was, and what was not, being targeted by Congress in 1996 - and why.

If the purported clear public policy against same-sex marriage on which antitransition-recognition courts (such as those in Texas, Kansas, Ohio and Florida) have hung their hats is a politico-legal construct which truly encompasses, in the negative (e.g., exclusion from the right to marriage) sense, a heterosexual marriage involving a transsexual and a non-transsexual of that person's pre-transition sex, then one would think not only that at least one of the now-39 enacted DOMAs would have explicitly mentioned transsexuals in its actual statutory language ${ }^{78}$ but

\footnotetext{
${ }^{76}$ Dana Priesing, 'DOMA, The Transgendered and Marriage', Transgender Tapestry, Fall 1996, 6, 47.

${ }^{77}$ Act of 21 September 1996, P.L. 104-199, 110 Stat. 2419.

${ }^{78}$ Not even the now-enacted Ohio 'SuperDOMA', which Judge Diane Grendell, in In re Nash and Barr, above n 28, improperly relied upon prior to its enactment, explicitly mentions transsexuals. Spencer Hunt, 'Gay-Marriage Fight Won't End', Cincinnati Enquirer, 6 February 2004, 1, 2004 WL 57343625; Stephen Ohlemacher, 'Taft Defends Gay Marriage Ban', Plain Dealer (Cleveland, Ohio), 7 February 2004, B3, 2004 WL 57886333; Lee Leonard and Mark Ellis, 'Taft Signs Law Banning Gay Marriage, Heads Off Possible Court Challenge', Columbus Dispatch (Ohio), 7 February 2004, 1A, 2004 WL 56491893. Previous Ohio DOMA bills did refer to In re Ladrach in their supporting documents - but only for the general anti-gay marriage proposition, and NOT addressing the salient pro-transsexual
} 
also that during each and every legislative debate on the issue of same-sex marriage since New Jersey's Appellate Division recognised such marriages as opposite-sex in M.T. V J.T. in 1976 - and, particularly during the 1996 debates on the federal DOMA - that the obvious conflict between what New Jersey viewed as a heterosexual marriage in M.T. and what other states view as a heterosexual marriage not only would have been discussed but would have been front-and-centre right along with Hawaii given that, unlike Hawaii, a pro-transsexual final decision (and almost two dozen transsexual birth certificate statutory enactments) had already come into being!

Far too many other courts have totally misconstrued the true meaning of transsexual birth certificate statutes. Although such statutes are ministerial and/or judicial mechanisms for correcting information on a transsexual's birth certificate to reflect post-transition reality, all such statutes also reflect the undeniable recognition, by the legislative body of the jurisdiction, of the reality of transsexualism irrespective of whether they are accompanied by a clear historical record similar to Louisiana's. This logical construct was recently cited in a brief to a Virginia federal court on behalf of an MTF prisoner suing the state for refusing to provide any transition related healthcare, and is viewed as being at least partially responsible for the Virginia Department of Corrections settling the case. ${ }^{79}$

The state-level jurisdictions which have statutorily recognised the concept of a legal change of sex do not form some small, liberal, elite cadre of north-eastern and/or 'left-coast' states seeking to impose their will on the vast majority of the states. As can be gathered from the chart in Part III C, it is a group - numbering just under half of the state-level jurisdictions in the United States - spread evenly across the widest cross-section of the nation imaginable: Northeast, Northwest, Southwest, Midwest and even the Deep South; states thought of as liberal, states thought of as moderate and states which are unquestionably conservative. Some of these statutes were passed after their respective states enacted anti-gay-marriage laws, ${ }^{80}$ some long prior. A not-insignificant number of them came into being prior to 1976's M.T. $v$ J.T., and some after, ${ }^{81}$ mandating an assumption that those states had knowledge of legally-recognised heterosexual marriages involving a transsexual and a member of

Ladrach dicta of Judge Denny Clunk, the individual judge who decided Ladrach. In other words, nothing is said about any purported pubic policy against recognition of out-of-state conformed birth certificates.

${ }^{79}$ Amicus Brief of Harry Benjamin International Gender Dysphoria Association, Inc., in Opposition to Defendant's Motion For Summary Judgment at पापा 31-32, De'Lonta v Angelone, No. C.A. \#7:99-CV00642 (WD Va, 2004). Full disclosure: I was a signatory to the brief and contributed this portion of the legal argument therein. The case had been remanded to the district court by: De'Lonta v Anglone, $330 \mathrm{~F}$ 3d 630 ( $4^{\text {th }}$ Cir, 2003). The settlement agreement was reached in late September 2004. 'Virginia Agrees to Treat Transsexual Inmates', Daily Press (Hampton Roads, Va.), 24 September 2004.

${ }^{80}$ Most recently, Maryland, whose anti-gay marriage statute was enacted in 1973 and whose transsexual birth certificate statute was enacted in 1995. Compare 1973 MD. LAWS Ch. 213; with 1995 MD. LAWS Ch. 97. Also, see generally, Part III C.

${ }^{81}$ It appears as though all of the states with such statutes except Illinois (1961), Arizona (1967), Louisiana (1968), Hawaii (1973), North Carolina (1975) and Iowa (12 February 1976) enacted their statutes after the New Jersey Appellate Division's decision in M.T. v J.T. See Chart, Part III C. Still, this represents roughly one-fourth of the statutes. 
her former legal sex. ${ }^{82}$ Some of these statutes were passed after their respective states repealed or otherwise nullified sodomy statutes, some prior; some, such as Missouri and Louisiana, still had active, enforceable sodomy statutes as of June 26, 2003, when the U.S. Supreme Court ruled in Lawrence v Texas. ${ }^{83}$

Only one state has ever purported to legislatively deny transsexuals' the ability to live unimpeded by documentation which, by virtue of gender transition, has become false. That state is Tennessee, not Texas, Kansas or Ohio. ${ }^{84}$ Moreover, if the Tennessee anti-transsexual language is accorded the same constrictive interpretation that the word "sex" is given by courts construing Title VII against transsexuals, then even that statute should be interpreted only to prohibit the amendment of the birth certificate and not as a rejection of the concept of transsexualism (in marriage or in any other context. ${ }^{85}$ ) Both were floor amendments to larger bills that received very little real consideration. Beyond this even, my research into the origin of this provision, which did occur approximately one year after M.T. v J.T., ${ }^{86}$ reveals no public concern in Tennessee about either the M.T. decision or the anti-transsexual birth certificate language. Neither appears to have rated any mention whatsoever in the major newspaper of the Tennessee state capitol of Nashville, The Tennessean. ${ }^{87}$

This leads to the question of whether M.T. v J.T., or any other transsexual case / statute might have played a role in spurring the passage of the federal DOMA.

\footnotetext{
${ }^{82}$ There should also be a mandatory assumption that Kansas had, or should have had, knowledge of M.T. $v J . T$. by the time of its first anti-gay-marriage law in 1980 - a law heavily relied upon in Gardiner - and could have included language explicitly excluding M.T. $v$ J.T.-esque marriages along with homosexual ones but did not do so. 'The legislature is presumed to act with knowledge of relevant judicial decisions.' In re Huerta, $41 \mathrm{P} 2 \mathrm{~d}$ 814, 821 (Kan, 2002) (quoting Johnson City Education Ass'n v U.S.D. No. 475, 955 P 2d 1266 (1998)). Although M.T. occurred outside of Kansas, M.T. is all but conclusive as to any discussion as to whether transsexuals were targeted by any anti-gay-marriage legislation passed in the years immediately afterward and which did not statutorily specify that transsexuals were targeted.

${ }^{83}$ Totally ignored in the Lawrence $v$ Texas litigation (as well as by the court which decided Littleton $v$ Prange) was that, in a previous challenge to the law declared unconstitutional in 2003, the state of Texas had put forth even the very possibility of undergoing a "surgical sex change" in an attempt to prove that a gay man did not have standing to challenge the law which criminalised certain activity only between members of the same sex. Baker $v$ Wade, 553 F Supp. 1121, 1147 (ND Tex, 1982), appeal dism'd 743 F $2 d 236$ ( $5^{\text {th }}$ Cir, 1984), rev'd on reh'g $769 \mathrm{~F} 2 d 289$ (5 $5^{\text {th }}$ Cir, 1985), cert. denied, 478 US 1022 (1986).

${ }^{84}$ TENN. CODE ANN. § 68-3-203 (d) (1999).

${ }^{85}$ Obviously, the Legislature could have included marriage-specific discriminatory language, but did not. This is not merely word/intent-parsing as, obviously, there are likely to be transsexuals in every state who were born in other states.

${ }^{86} 1977$ TENN. ACTS Ch. 128, § 21.

${ }^{87}$ I have reviewed the Tennessean from March of 1976. Although there was one article about a transgendered person (a prostitute in Miami), which actually appeared the day prior to the M.T. decision, nothing transgender-related (much less transsexual-related) appeared in the March $23^{\text {rd }}$ issue. 'Officer Discovers 'Ugly' She Was He', The Tennessean, 21 March 1976, 20-A. The front page of the March $23^{\text {rd }}$ issue did include, in addition to hard news items, no less than two entertainment-related items: one on Hank Williams, Jr; , and one on Andy Williams' ex-wife Claudine Longet. George Watson, Jr., 'Hank Williams 'Fine' After Forehead Surgery', The Tennessean, 23 March 1976, 1-A; 'Claudine Now Facing Charges in Shooting', The Tennessean, 23 March 1976, 1-A.
} 


\section{$2 \quad$ Looking For M.T.}

Even vehemently anti-gay-marriage commentators, in attempting to prove that 'the people' could not possibly envision marriage as anything other than a union between one man and one woman, have, for their proposition cited M.T. vJ.T. - a case which as explicitly as can be imagined declared that a heterosexual marriage between a post-surgical transsexual and a person of the transsexual's pre-transition sex was not a same-sex marriage. ${ }^{88}$ Going back further, one can find absolutely no mention in the legislative history of the federal DOMA of concern over legal recognition of such a marriage.

Neither the majority report nor the dissenting report of the House Judiciary Committee say anything whatsoever about (for or against) the idea of the marriage in M.T. v J.T. - or any heterosexual marriage involving a transsexual from any of the states which had by then statutorily recognised the concept of transsexualism being considered an opposite-sex marriage. The majority report even states, in language that could not be more unequivocal, that that bill was 'a response to a very particular development in the State of Hawaii. ${ }^{89}$ And, that development in Hawaii was most certainly not the recognition of transsexualism by that state's legislature in $1973 .{ }^{90}$

It was the Baehr litigation.

In committee, Senator Orrin Hatch said that the DOMA bill 'responds to several key questions': whether there was a 'serious practical problem' that Congress needed to address (his answer: the Hawaii litigation); whether the 3-2 majority of the Hawaii Supreme Court can force other states 'to alter radically the concept of marriage' (his answer: yes; this obviously still refers to Baehr); and whether DOMA would be a 'legitimate exercise of Congress' power.' ${ }^{91}$ Senator Don Nickles, in response to comments from Senator Ted Kennedy regarding Kennedy's

\footnotetext{
${ }^{88}$ See Katherine Shaw Spaht, 'Beyond Baehr: Strengthening The Definition of Marriage', (1998) 12 Brigham Young University Journal of Public Law 277, 285-86. Spaht, a Louisiana State University law professor, is a supporter of the Louisiana anti-gay-marriage amendment. Kevin McGill, 'Senate Panel OKs Gay Marriage Ban', The Advocate (Baton Rouge, La.), 4 May 2004,

Available on-line at: <http://2theadvocate.com/stories/ 050404/new_notogay001.shtml> (last visited 11 May 2004)

${ }^{89}$ H. Rep. No. 104-664 (1996), reprinted in 1996 U.S.C.C.A.N. 2907. Both Rep. Charles Canady, in the House Judiciary Subcommittee hearing on DOMA, and Sen. Orrin Hatch, in the Senate Judiciary Committee hearing, led off their respective hearings by referring specifically - and only - to the thenongoing Hawaii Baehr same-sex marriage litigation. Hearing Before the Subcommittee on the Constitution of the Committee on the Judiciary, House of Representatives, $104^{\text {th }}$ Cong., $2^{\text {nd }}$ Sess., on H..R. 3396, at 2 (15 May 1996) (Serial No. 69) (hereinafter 1996 House Hearing); Hearing Before the Committee on the Judiciary, Senate, $104^{\text {th }}$ Cong., $2^{\text {nd }}$ Sess., on S. 1740, at 1 (11 July 1996) (Serial No. J-104-90) (hereinafter 1996 Senate Hearing).

${ }^{90} 1973$ HAW. ACTS. No. 39, codified at HAW. REV. STAT. ANN. § 338-17.7 (West 2003).

${ }^{91}$ Senate Committee Hearing, 1-2 (statement of Sen. Hatch).
} 
characterisation of the DOMA bill as intolerant as well as Kennedy's proposed attachment of the Employment Non-Discrimination $\mathrm{Act}^{92}$ to the bill, stated:

I didn't instigate the Hawaii decision. I didn't file the petition before the court in Hawaii. I wasn't the President's liaison to the homosexual activists that is talking about gay marriages - or same sex marriages. So the timing of this was really brought about by the Hawaiian decision and by several activists that want to have same-sex marriages recognised throughout the country. ${ }^{93}$

Nickles indeed did not instigate the Baehr decision. But, likewise, neither did transsexuals. As a general proposition, transgendered people have historically been all but totally excluded from gay rights policymaking, even when such policymaking is declared to be in the name of not just gays, lesbians and bisexuals but also the transgendered. Transsexuals have never been allowed to testify at any of the hearings which have been held concerning adding a non-transgender-inclusivelydefined "sexual orientation" to the categories addressed by federal employment anti-discrimination law. ${ }^{94}$ Few transsexuals have ever been employed by any of the major gay rights organisations - the organisations that, historically, have played major roles both in developing the trans-non-inclusive track record of civil rights legislation and in spearheading the modern gay marriage pushes. ${ }^{95}$

Apparently, the only time that the word "transsexual" appeared in the Congressional Record during the $104^{\text {th }}$ Congress, of 1995-96, was NOT during floor debates over DOMA, but in comments by Sen. Dan Coats on July 31, 1995, attacking the United Nations' Beijing Conference on the Status of Women, claiming that:

When several delegates sought to define gender, their efforts were rebuffed. Behind the scenes, it became evident that the meaning of gender had been expanded to include not just male and female, but transsexual, bisexual and homosexual. ${ }^{96}$

\footnotetext{
${ }^{92}$ An amendment which, like all federal gay employment anti-discrimination proposals which came before it and which have come after it, had it been successful, only would have protected homosexuals, heterosexuals and bisexuals, not transsexuals or any transgendered people.

${ }_{93}$ Above n 91, 9-10 (emphasis added) (comment of Sen. Nickles).

${ }^{94}$ Phyllis Randolph Frye, 'Facing Discrimination, Organizing For Freedom: The Transgender Community', in John D'Emilio (ed), Creating Change (2000) 451, 462. Ms. Frye and another transgender rights activist were, however, allowed to submit prepared written statements with respect to the 1994 ENDA hearing. Karen Ann Kerin, 'Proposed Amendments to Civil Rights Law', Senate Labour Committee (29 July 1994), 1994 WL 392888 (F.D.C.H.); Phyllis Randolph Frye, 'Federal "Sexual Orientation" Employment Bill Must Include the Transgendered', Senate Labour Committee (29 July 1994), 1994 WL 392889 (F.D.C.H.).

${ }^{95}$ Cartwright, above n 29 (imploring HRC to 'hire transgender-identified people as soon as possible for prominent, visible staff positions, preferably those that involve regular contact with legislators,' something the organisation has a long history of not doing).

${ }^{96}$ Congressional Record, $104^{\text {th }}$ Cong., $1^{\text {st }}$ Sess., at S10965.

It must be noted that the Senator goes on to ponder, 'I wonder how many Americans consider 'gender' to be relative,' followed by the assertion, 'The definition of gender is sex, that is male or female, period' This clearly indicates that the Senator is unwilling to acknowledge the existence of any form of intersexuality.
} 
The only other occurrence of the word came via Sen. Jesse Helms the following day on the same subject. ${ }^{97}$ And, the word appears nowhere in House debate.

The phrase "sex change" appears four times, only three of which actually involve transsexuals, ${ }^{98}$ though none of the four appear in any manner in connection with DOMA. $^{99}$ Other transgender concepts appeared in the Congressional Record during the $104^{\text {th }}$ Congress, but none in connection with DOMA, and certainly not in connection with any scintilla of any possible hint that DOMA was intended to preempt M.T. v J.T. or any effect of any transsexual birth certificate statute. While clear that those who spoke on transgender issues that session despised transgendered people, hate-filled talk does not equate to hate-filled action; passage by Congress and presentment to the Executive Branch is required. ${ }^{100}$

Referring back to the DOMA hearings, the broad category of transgendered people actually was mentioned, albeit non-substantively, in the prepared statement of the National Gay-Lesbian Task Force (NGLTF). And, well-known right-wing extremist Gary Bauer mentioned "transvestites" in a hypothetical dealing not with DOMA itself but the attempt to attach ENDA to it. ${ }^{101}$ Bauer said nothing about transsexuals or transsexual marriage, however. Likewise, neither did Jay Sekulow, counsel for the Pat Robertson-associated, right-wing American Center for Law and Justice $(\mathrm{ACLJ}),{ }^{102}$ and a man who actually helped draft DOMA. ${ }^{103}$ Notably, Sekulow did quote from a New Jersey newspaper article about homosexuals awaiting the outcome of the then-ongoing Hawaii litigation. ${ }^{104}$

At the risk of sounding repetitive, the question as to transsexuals had by then been settled in New Jersey - and in favour of transsexuals. Does it not seem reasonable, indeed rational, to believe that if the 1996 DOMA was intended to target that then-

\footnotetext{
${ }^{97}$ Congressional Record, $104^{\text {th }}$ Cong., $1^{\text {st }}$ Sess., S1 1050.

98 The fourth occurred in a reprint of a Long Island Newsday article, and did not involve transsexuals but, rather, constituted part of a somewhat snide comment about lobbyists: 'You can tell when something big is happening at the House Ways and Means Committee. The lobbyists all age by about 25 years and undergo sex-change operations, as the powerful replace the mere note-takers.' Ibid. H11920 (8 Nov 1995) (reprinting Marie Cocco, 'The New Tax-Free Corporate Checking Account', Newsday, 21 September 1995).

${ }^{99}$ One involved Rep. Kingston complaining that Atlanta's Legal Aid Society had handled a case involving a transsexual's quest for Medicaid funding for SRS. Congressional Record, $104^{\text {th }}$ Cong., $2^{\text {nd }}$ Sess., H5494 (22 May 1996). The other two were references to inmate suits for SRS. Ibid. S3703; and S14629.

${ }^{100}$ See generally, Clinton v City of New York, 524 US 417 (1998); and INS v Chadha, 462 US 919 (1983).

${ }^{101}$ It must be further noted that Bauer's example pertained to housing, something that has not been covered, even as to sexual orientation, by any of the ENDA bills. Even the pre-ENDA Civil Rights Act amendment bills did not include housing, though many did include public accommodations, public facilities and educational opportunities. See generally, H.R. 166, $\S \S 2-4,94^{\text {th }}$ Cong., $1^{\text {st }}$ Sess. (1975)

1021996 House Hearing at 214-28 (testimony and prepared statement of Jay Alan Sekulow).

${ }^{103}$ CSPAN Television, Washington Journal, Same-Sex Marriage (12 July 2004) (call-in show featuring Sekulow and HRC's Cheryl Jacques) (copy on file with author).

${ }^{104} 1996$ House Hearing at 223 (quoting 'Will Hawaii Redefine Marriage? N.J. Couples Eagerly Await Word', The Record, 9 May 1996).
} 
two-decade-old precedent (and all law in line with it from other states) or even if Sekulow and his organisation wanted DOMA to do so, then one of the most antiGLBT legal organisations in the country would have said something about it in a forum not only controlled by radically conservative Republicans but also in which even some of the most anti-DOMA voices, such as Sen. Ted Kennedy and Rep. Barney Frank, are well-known to be unfriendly to the transgender community? ${ }^{105}$

There is, of course, only one logical answer.

And yet, the evidence of trans-non-inclusion does not end with Sekulow.

\section{Testimony}

Pro-DOMA Professor Hadley Arkes stated bluntly of DOMA: 'This statute upsets no judgment of the courts. ${ }^{, 106}$ If this was a true statement on May 15, 1996, then neither the federal DOMA nor any state statute modelled after it ${ }^{107}$ can be regarded as having been aimed at a marriage that unquestionably would be valid under the M.T. v J.T. reasoning of March 22, 1976; such a marriage would implicitly, and logically, be valid in any state that has recognised the reality of transsexualism by enacting a birth certificate statute.

Lynn Wardle, another pro-DOMA academic who presented testimony to both houses, said of the definitions of "marriage" and "spouse" that

sometimes these terms are used in federal law in a manner that suggests that Congress believed that the definition of "marriage" used in state law would be satisfactory for the federal law. Since the differences in state marriage laws (though numerous) were relatively minor, and since no state allowed such radical reconstruction of marriage as same-sex marriage, the passive presumption of adoption of state law has worked quite well. If some state legalized same-sex marriage, that would radically alter a basic premise upon which the presumption of adoption of state domestic relations law was based - namely, the essential fungibility of the concepts of "marriage" from one state to another. Section 3 accurately declares the premise upon which two centuries of federal legislation using marriage terms has been predicated. ${ }^{108}$

Wardle also elsewhere prefaces legalisation of same-sex marriage with the word "if." 109 Clearly, he is referring to something that had not yet occurred in any state. This must be repeated: the decision in M.T. v J.T. had happened in New Jersey two decades prior! Wardle obviously was referring to gay, homosexual, same-sex marriage, and not a heterosexual marriage in which one spouse is a post-transition

\footnotetext{
${ }^{105}$ Frye, 'Facing Discrimination', above n 94, 465-66.

1061996 House Hearing, 88 (testimony of Hadley Arkes).

${ }^{107} \mathrm{Or}$, presumably, similar to it but which may already have been in existence.

1081996 House Hearing, 168 (prepared statement of Prof. Lynn Wardle) (emphasis added).

${ }^{109}$ Ibid 178; 1996 Senate Hearing, 27, fn. 4 (prepared statement of Prof. Lynn Wardle).
} 
transsexual and the other spouse is a member of the transsexual spouse's pretransition sex. If he was referring to the latter, then certainly there would have been some mention of M.T. v J.T., In re Ladrach (at that point the most recent published decision on transsexual marriage ${ }^{110}$ ), and, given the historical tenor of his statements, Peipho v Peipho, an 1878 Illinois decision upholding a marriage between a man and a "hermaphrodite,"111 and the even older case of Thomasine Hall, an intersexed person who an early colonial court in Virginia ruled to be both male and female. $^{112}$

Wardle also utilised an example of a same-sex couple from Utah going to Hawaii to get married, getting a judgment related to their marriage, and bringing it back to Utah to demand recognition of it which, according to Wardle 'would flaunt and undermine a strong public policy of Utah (which strongly favours and protects heterosexual marriage exclusively). ${ }^{113}$ Again with this example, the public policy implicit in transsexual birth certificate statutes demands that this DOMA (and, by extension, all DOMAs) be interpreted in favour of transsexuals: By 1996 the legislatures of both Hawaii and Utah had long since enacted statutes officially acknowledging the medical reality of transsexualism and the legal reality of change of sex. ${ }^{114}$

\section{$4 \quad$ Revisionism and Non-Revisionism}

DOMA sponsor Rep. Bob Barr, was quoted seven years after the DOMA hearings as saying that the issue of DOMA's applicability to transsexuals actually had arisen in 1996 via a question from a Representative from North Carolina. According to Barr (in 2003), his response in $1996^{115}$ was the smug: 'The people of Georgia know what a man is and what a woman is. I don't know if you're having problems up in North Carolina. ${ }^{, 16}$ Both states, however, by then had enacted statutes officially acknowledging the reality of transsexualism: North Carolina in 1975 and Georgia only seven years later (meaning, significantly, that Barr's home state of Georgia had enacted its statute after M.T. v J.T., so it must be presumed to have known what it was doing). ${ }^{117}$ Barr's comment cannot be interpreted, absent inherent antitranssexual bias, to mean that DOMA actually was designed to deem certain heterosexual couples to be homosexual couples. Rather, it must be interpreted as revisionism on Barr's part in 2003 and/or a total lack of knowledge on his part about

\footnotetext{
${ }^{110}$ Ladrach, above $\mathrm{n} 40$

${ }^{111} 88$ Ill 438 (1878) (the word "hermaphrodite" appears in the syllabus, not the opinion).

${ }^{112}$ See Katrina C Rose, 'A History of Gender Variance in Pre-20 $0^{\text {th }}$ Century Anglo-American Law' (2004)

14 Texas Journal of Women \& the Law (forthcoming).

1131996 House Hearing, 180; 1996 Senate Hearing, 36 (prepared statement of Lynn Wardle).

1141981 UTAH LAWS Ch. 126, § 3; 1973 HAW. ACTS. No. 39.

${ }^{115}$ Which I have been unable to find evidence of in the pertinent transcripts.

${ }^{116}$ Paul Schindler, 'Has the Right Been Muted', Gay City News, 28 February - 6 March 2003,

<http://www.gaycitynews.com/gen209/hastherightbeenmuted.html> (last visited 11 January 2004) (quoting Bob Barr).

${ }^{117} 1982$ GA. ACTS. No. 1216, § 1; 1975 N.C. LAWS Ch. 556.
} 
transgender law in 1996. ${ }^{118}$ In light of this it is not insignificant that at least twice in 2004 testimony before congressional committees dealing with gay marriage, Barr said nothing about transsexuals. ${ }^{119}$

Gary Bauer, on the other hand, did take up the subject of transsexual marriage in 2003, though arguably - and significantly - without any overt revisionism. In a missive entitled The Attack on Marriage, which can be found on the Campaign For Working Families website, he questions the ultimate viability of the federal DOMA via a portrait of what he styled 'the 'brave new world' we are currently living in': ${ }^{120}$ a comparison between the outcomes of heterosexual transsexual marriage cases in Illinois (in which a judge ruled that an FTM was still a woman) ${ }^{121}$ and Florida (in which a judge, in an 800 page opinion, ruled that an FTM was a man.) ${ }^{122}$ It is actually unclear whether, in 2003, he regarded both of these marriages as actually having been encompassed by the 1996 act or that "traditional values" had subsequently been 'discarded for moral relativism.' ${ }^{123}$ Irrespective of whether he did or

\footnotetext{
${ }^{118}$ My personal suspicion is that it is the latter - even though he may have felt he was accomplishing the former.

${ }^{119}$ Bob Barr, Testimony to the House Judiciary, Subcommittee on the Constitution, 30 March 2004, <http://www.house.gov/judiciary/barr033004.pdf> (last visited 2 May 2004); Hearing on the Proposed Federal Marriage Amendment, above n 71 (testimony of former Rep. Bob Barr). In the June hearing (where the other witnesses were Rep. Musgrave and Gov Mitt Romney of Massachusetts), in approximately 40 minutes of testimony and questioning, primarily by Sen. Hatch, Barr never mentioned transsexuals. Notably, during his colloquy with Barr, Hatch (as he has in other committee hearings and on the Senate floor), utilised the following phraseology:

$[\mathrm{M}]$ any of our friends on the other side, and even some on our side, from time to time love to have the courts do for them that which they could never get through the elected representatives of the people. And in this particular case, as your experience shows with DOMA, with 40 states basically approving it, I doubt that they could get this changed in the law of marriage - away from traditional marriage, to, to same-sex marriage - I doubt they could get that in any state in the union through the elected representatives of the people.
}

If Hatch, Musgrave and the other FMA supporters were to contend that it is indeed intended to wipe out transsexual marriages, then, given the 25 state-level jurisdictions that have unquestionably approved of transsexualism via their legislatures, courts interpreting the FMA will have to contend with statements such as this - which, in an 'FMA targets transsexuals' construct, will be as egregiously inaccurate as can be imagined. Also during this portion of the hearing, Sen. Jeff Sessions of Alabama remarked, 'No legislature, no state, Mr. Barr, since the founding of this Republic, has ever voted to define marriage other than between a man and a woman.' Though Sessions was never an Alabama state legislator, he was once its Attorney General - meaning that, in theory, he had authority to issue opinions interpreting Alabama's transsexual birth certificate statute. 'Senator Jefferson B. 'Jeff' Sessions (AL)', PROJECT VOTE SMART, <http://www.vote-smart.org/bio.php?can_id=BC034032> (last visited 26 September 2004); 1992 ALA. ACTS No. 92-607, § 19.

${ }^{120}$ Gary Bauer, 'The Attack on Marriage', cwfpac.com, 14 August 2003 <http://www.cwfpac. com/newsletter.php?id=08140301> (last visited 11 April 2004) (emphasis added).

121 'Illinois Court Rules Against Transgender Father', Illinois Gender Advocates Newsletter, May 2003, $1-2$.

${ }^{122}$ Kantaras v Kantaras, No. 98-5735CA (Fla Cir Ct, Pasco Co, 21 February 2003).

${ }^{123}$ Bauer, above n 120. Notably, the Family Research Council, an organisation that Bauer headed at the time of the DOMA hearings, published a guide to model so-called pro-family legislation in 2003. Of course, 'pro-family' has been morphed by religionists into being synonymous with 'anti-gay' and, usually, 'anti-GLBT.' However, of the 16 pieces of legislation utilised in the book, the only two pertinent ones were the Ohio Super DOMA bill and Utah's anti-gay-adoption bill. Nothing is mentioned in the section accompanying the Ohio bill regarding the unclear status of transsexuals in that state. More 
did not, again missing from the equation is the pre-DOMA M.T. v J.T. And, equally important is word "new," which I emphasised, because, however he may now portray his mindset as being regarding a federally-mandated definition of marriage, he unquestionably had the opportunity to elucidate on heterosexual transsexual marriage in testimony to Congress in 1996 (something no transsexual was allowed to do, and something that no gay, lesbian or heterosexual person who testified did do.)

Now, despite Barr's apparently-revisionistic 2003 anecdote and Bauer's apparent post-1996 discovery of the fact that heterosexual transsexual marriage is not samesex marriage, ${ }^{124}$ the one 1996 DOMA-related mention of gender variance in the context of legal identity and marriage appears actually to have come in the prepared statement of Ernest Chambers, a member of the Nebraska Legislature:

If, as many argue, every human being is "created" heterosexual; that "God makes no mistakes" and that the locus of sexual orientation is in the genitals, what is the "genetic" sexual orientation of the hermaphroditic person who is "created" with both female and male sexual organs? Would not such a person be "homosexual" regardless of which gender was preferred? And would it not be "genetic"?

In light of Chambers being a legislator there, it must be noted that Nebraska by then had had a transsexual birth certificate statute (albeit for only two years.) Not until 2000 did it enact its 'SuperDOMA.' It must also be noted that searches in the Allnews database on Westlaw regarding Initiative 416 (the popular name for $\mathrm{Ne}$ braska's 'SuperDOMA') revealed 205 items on the measure, ${ }^{126}$ but only one that also mentioned transsexuals - and that item was dated several months after the measure passed. ${ }^{127}$ Speculation in recent commentary is that the 'practical implications' of Initiative 416 'are not fully understood.' 128 However, if heterosexual

importantly, though, the book did not include, as one of its 'models', the 1977 Tennessee anti-transsexual birth certificate statute. Family Research Council, State Model Legislation Guide 2003 (2003) 39-41, 61-68.

${ }^{124}$ Still, transsexual marriage was not addressed in a debate in 2004 between Bauer and now-former HRC head Elizabeth Birch. Eric Resnick, 'Gary Bauer, Elizabeth Birch Spar in Debate on Marriage', Gay People's Chronicle, 1 October 2004,

<http://www.gaypeopleschronicle.com/ stories04/04oct1.htm\#story4> (last visited 4 October 2004). This news item isn't a transcript, of course. However, the reporter informed me via e-mail that neither Birch nor Bauer mentioned transsexuals. 'E-mail from Eric Resnick to Katrina Rose' (4 October 2004, 5:59 PM CDT) (copy on file with author).

1251996 House Hearing, 70 (prepared statement of Sen. Ernest Chambers).

126 "Initiative 416" \& DA(AFT 01/01/1998), Westlaw search, ALLNEWS database, run 24 October 2003. The beginning date was chosen simply to encompass any early discussion on the initiative that might appear. The earliest item retrieved by the search is dated 14 September 2000.

${ }^{127}$ The 'item' was the letters-to-the-editor section of the June 26, 2001 edition of the Omaha WorldHerald, but "Initiative 416" and "transsexuals" appeared in separate letters. 'Public Pulse', Omaha World-Herald, 26 June 2001, 14, 2001 WL 9579516. Taking this into account, there were no items about both the initiative and transsexuals.

${ }^{128}$ Angela Dunne Tiritilli and Susan Ann Koenig, 'Advocacy For Nebraska Children With Gay and Lesbian Parents: A Call For the Best Interests of the Child to be Paramount in the Case of NonBiological, Non-Adoptive Parents' (2002/2003) 36 Creighton Law Review 3, 7. 
marriage involving transsexuals had any connection with same-sex marriage, at least outside of the imagination of anti-GLBT judges, then there would certainly be some further connection between the two in the public discourse over that citizen initiative, ${ }^{129}$ particularly given the existence in the state not just of the birth certificate statute but also the situs of one of the most well-known hate-crime murders of a transgendered person. ${ }^{130}$

\section{$5 \quad$ Massachusetts}

Massachusetts, home of a transsexual birth certificate statute since $1981^{131}$ and situs of several transsexual hate-crime murders, ${ }^{132}$ is home to ground zero in the gay marriage debate in 2004. And, transsexuals' concerns are absent from that debate. While it would be impossible to detail all discussions which evidence transabsence, one event of interest is a recent debate on same-sex marriage at Boston University. ${ }^{133}$ Mary Bonauto, counsel for the plaintiff couples in Goodridge, in her opening remarks stated that there were no objections when the U.S. Supreme Court

Interestingly, a documentary on the enactment of the measure not only does not include any mention of any possible effect on transsexuals' rights by Initiative 416 , when the documentary refers to general Nebraska GLBT history it refers to Brandon Teena as 'Teena Brandon' and with female pronouns. 416 (Apartment 101 Films, 2004).

${ }^{129}$ Admittedly, not all of the items also contained gay-specific terms as well. "Initiative 416" \& (GAY LESBIAN HOMOSEXUAL \& "SAME SEX") \& DA(AFT 01/01/1998), Westlaw search, ALLNEWS database, run 24 October 2003. This lowered the number of items retrieved to 120 , but the absence of any reference to transsexuals remains.

There is also no indication whatsoever that a Nebraska statute which actually is obviously antitranssexual, namely the alignment in 1993 of that state's disability anti-discrimination law with the transgender-exclusion language of the federal Americans with Disabilities Act, 1993 NEB. L.B. 360, $\$ 3$, could in any way have pre-emptively abrogated the explicit recognition of transsexualism by that same legislative body the following year when it enacted a transsexual birth certificate statute. 1994 NEB. L.B. 886, § 4, codified at NEB. REV. STAT. § 71-604.01 (2003). It is fully within the bounds of legal logic for a state to recognise transsexualism as a legitimate medical condition and to recognise the logical end of a treatment regimen (namely, a full change of sexual status), but, at the same time, decide that such condition is not necessarily cause for a transsexual person to be able to challenge employment discrimination based on transsexualism as a disability (as opposed to sex.) Nebraska would not be unique. Prior to 2000, California, despite its 1977 transsexual birth certificate statute, utilised the antitranssexual language of the federal disability construct. See 2000 CAL LAWS Ch. 1049; and Bernice Yeung, 'Better Than Nothing', SF Weekly, 18 April 2001, <http://www. sfweekly.com/issues/2001-0418/bayview.html/1/index.html>. Consequently, the Nebraska ADA should not be read in conjunction with Initiative 416 to manufacture non-recognition public policy. After all, it was after it had adopted the anti-transsexual federal language that the Nebraska Legislature enacted its transsexual birth certificate statute!

${ }^{130}$ See The Brandon Teena Story (Gréta Olafsdóttir and Susan Muska, dir. 1998); see also, State v Lotter, 669 NW 2d 438 (Neb, 2003); State v Lotter, 664 NW 2d 892 (Neb, 2003); Brandon v County of Richardson, 653 NW 2d 829 (Neb, 2003); Brandon v County of Richardson, 624 NW 2d 604 (Neb, 2001); State $v$ Lotter, 586 NW 2d 591 (Neb, 1998); Brandon v County of Richardson, 566 NW 2d 766 (Neb, 1997); State $v$ Nissen, 560 NW 2d 157 (Neb, 1997).

${ }^{131} 1981$ MASS. ACTS. Ch. 684.

${ }^{132}$ Nancy Nangeroni, 'The Murder of Chanelle Pickett', <http://www.rememberingourdead.org/ people/chanellepickett.html> (last visited 2 May 2004).

${ }^{133}$ CSPAN Television (USA), American Perspectives, 'Should Government Accept Same-Sex Marriage' (10 April 2004) (debate taped 7 April 2004). 
overturned restrictions on interracial marriage in $1967,{ }^{134}$ restrictions based on poverty-related matters in $1978,{ }^{135}$ and restrictions based on felon status in $1987 .{ }^{136}$ Apart from the fact that in no way was the landscape as placid as she depicted it in the immediate aftermath of Loving, ${ }^{137}$ quite telling is an example that she did not give: the transsexual marriage validated in 1976 in New Jersey in M.T. $v$ J.T. Admittedly, she was citing examples of decisions of finality by the U.S. Supreme Court, but the final word on the meaning of Massachusetts Constitution, insofar as a reading of it recognising same-sex marriage, is no more of an issue for the U.S. Supreme Court than would have been the decision of New Jersey's courts upholding the view that the concept of 'sex' in that state encompassed recognition of the reality of transsexuals and transsexualism.

Also speaking in favour of gay marriage at Boston University was Jonathan Rauch, ${ }^{138}$ positing that he can in reality marry no one if he cannot marry a male, and asserting that historically only two groups ever have been so prohibited: slaves and children. ${ }^{139}$ Although the logical conclusion to various rationales (chromosomes, procreation, etc.) behind closing the doors of marriage to transsexuals has apparently never materialised in an American court (namely, that a transsexual can marry no one), it did gel in an Australian court with respect to the marital rights of an intersexed person, and only a quarter-century ago. ${ }^{140}$ Genevieve Wood, of Gary Bauer's former group, the Family Research Council, went to the 'bisexual orientation' slippery slope argument - asserting that there would be no reason for a bisexual person to demand the right to be married to one person of the same sex and one of the opposite sex. Notably, in all of her arguments regarding marriage and the family structure, she said nothing about transsexual marriage, ${ }^{141}$ a fact notable in and of itself as to Massachusetts. However, the current head of the FRC, Tony Perkins, was a Louisiana state representative in 1999 when its DOMA statute - that said nothing about transsexuals even though the state had had, for over three decades at that point, a transsexual birth certificate statute - was enacted. In fact, he was even a co-sponsor of it. ${ }^{142}$

\footnotetext{
${ }^{134}$ Loving v Virginia, 388 US 1 (1967).

${ }^{135}$ Zablocki v Redhail, 434 US 374 (1978).

${ }^{136}$ Turner $v$ Safley, 482 US 78 (1987).

${ }^{137}$ Certainly while there was no rush of hysteria approaching that enveloping the possibility of legalised same-sex marriage, it cannot be said that there was no opposition - particularly to Loving. State constitutional provisions of the variety rendered unenforceable by Loving remained in existence into the 1990's, and even then the referendum to remove the provision passed by only a not-so-overwhelming margin. 'Controversial Amendments', The Herald (Rock Hill, S.C.), 5 November 1998, 11A, 1998 WL 7646279.

${ }^{138}$ Jonathan Rauch, Gay Marriage: Why it is Good for Gays, Good for Straights, and Good for America (2004).

${ }^{139}$ American Perspectives, above n 133.

${ }^{140}$ Specifically, In re the Marriage of $C \& D$ (falsely called $C$ ). As noted above, above $\mathrm{n} 23$, with the more recent decisions in Australia recognising transsexualism, it is doubtful that $C \& D$ is still good law. However, the fact that such a decision occurred as recently as it did cannot be ignored.

${ }^{141}$ American Perspectives, above $\mathrm{n} 133$.

1421999 LA. H.B. 1450 (engrossed).
} 
Hadley Arkes, who had testified at the 1996 DOMA Hearings in favour of DOMA, failed to mention transsexuals at the Massachusetts event. ${ }^{143}$ Likewise, so did the two student debaters on the panels. And, the matter was not mentioned by the audience members (both pro- and anti-same-sex marriage) who posed questions/comments to the panel. Of course, this is no different than the recent DOMA oversight / FMA-precursor hearings and the rhetoric leading to them. Akin to her statement this year, a press release issued by Rep. Musgrave in response to the November 2003 decision from the Massachusetts Supreme Judicial Court implies that nothing "non-traditional" had ever previously been recognised. 'Gay marriage activists that have been shopping around for judges willing to overturn this tradition finally found their sympathetic bench. Overnight these judges pulled up the rug and found a new right for gay marriage. ${ }^{, 144}$

Moreover, in a five-page (yet detailed) document issued following the clarification decision in February, the U.S. Senate Republican Policy Committee railed against the "judicial activism" in Massachusetts and detailed past pushes for gay marriage (namely, Alaska and Hawaii) and even did mention New Jersey. However, the mention was not of M.T. $v$ J.T. Rather, it was the ongoing gay marriage case of Lewis $v$ Harris. ${ }^{145}$ Transsexual marriage is not mentioned even with respect to states where it has been the subject of litigation. ${ }^{146}$ Similarly, in a lengthier document issued in 2003 in the aftermath of Lawrence $v$ Texas, New Jersey is mentioned - but, again, not for M.T. v J.T.; rather, it was for the Boy Scouts v Dale litigation. ${ }^{147}$

\footnotetext{
${ }^{143}$ Although, he did manage to bring up NAMBLA (the 'North American Man-Boy Love Association', a group, to whatever degree it actually exists at any given time, which is synonymous with paedophilia) and to liken opposition to same-sex marriage to opposition to the Patriot Act because of the unknown possibilities of each. American Perspectives, above $\mathrm{n} 133$.

144 'Marriage is in Clear and Present Danger' (Press Release, 18 November 2003), <http://johnshadegg. house.gov/srs/word/Musgrave112403.pdf> (last visited 2 May 2004).

${ }^{145}$ No. MER-L-S-03, 2003 WL 23191114 (NJ Super Law Div, 5 November 2003).

146 Republican Policy Committee, 'Judicial Activism Forces Same-Sex Marriage on the Nation', <http://rpc.senate.gov/_files/Feb1104Marraige2SD.pdf> (last visited 2 May 2004).

${ }^{147}$ Republican Policy Committee, 'The Threat to Marriage From the Courts', <http://rpc.senate.gov/_files /CIVILsd090403.pdf> (last visited 2 May 2004).

Notably, in another such document from 2003 - this dealing with the proposed federal hate crimes law which contains language that some feel is inclusive of all transgendered people - this 'Policy Committee' clearly indicates that it knows the difference between homosexual and transsexual. Republican Policy Committee, "The Kennedy "Hate Crimes" Bill: An Unwise Proposal', 2 <http://rpc.senate.gov/ _files/CRIMEcr071503.pdf> (last visited 15 June 2004) ("every crime where the victim is a homosexual, a transsexual, a transvestite, disabled, or a known member of a religion'). In a footnote referring to a congressional committee report which included language expounding on the breadth of the word "gender" in the bill, the 'Policy Committee' summarised by stating that the congressional report gave "examples of crimes against persons dressed up as members of the opposite sex and against transsexuals, and indicat[ed] that the Kennedy bill would apply to those crimes." Ibid. fn. 2; and 4, fn. 13. There is obvious cognisance, and tacit recognition, of a difference between transvestites and transsexuals. The closest that this 'Policy Committee' report comes to actually challenging the legal legitimacy of gender transition (despite hyperbole about such "behaviour" offending certain people's "deeply-felt moral convictions") is the impotent single placement of quotations around the phrase 'sex change' when referring to sex reassignment surgery - something that even many in the pro-recognition camp do based on the belief that the phrase is outmoded, with SRS, GRS or CGRS being more medically appropriate. Ibid 11.
} 
And yet, with all of this as the backdrop, 'The heavy hand of DOMA has fallen with particular severity on transsexuals, regardless of their sexual orientation. ${ }^{148}$

\section{The DOMA Mindset in General}

$1 \quad$ The Effect on Transsexuals

(a) Littleton and Gardiner

On October 27, 1999, an intermediate appellate court in San Antonio, Texas, issued an opinion upholding a trial court's invalidation of a heterosexual marriage between a male-to-female transsexual and a non-transsexual male. ${ }^{149}$ Although inherently disheartening to the surviving party to the marriage (the wife) and to transsexuals throughout Texas and America, the bare ruling was not inherently shocking, though a contrary positive ruling actually would not have been particularly shocking either. That decision was Littleton v Prange. Prior to it, case law existed on both sides of the gender-transition recognition aisle, though, by far, the heavy weight of authority by 1999 tilted in favour of recognition. ${ }^{150}$

What was shocking to many, and what will always make Littleton stand out as a landmark decision, albeit a negative one, is that it was apparently the first instance of any court in the United States citing the federal DOMA to invalidate a marriage that had been assumed by all involved - not simply the parties themselves but those with whom they interacted and even at least one arm of state government ${ }^{151}$ - to be a legal heterosexual, opposite-sex marriage. ${ }^{152}$ As the words of a song that was popular earlier that year had intoned, 'The real troubles in your life are apt to be things that never crossed your worried mind, the kind that blindside you at 4 p.m. on an idle Tuesday. ${ }^{153}$ So it was with Littleton $v$ Prange when the Texas transsexual community learned of the case that fall, ${ }^{154}$ and saw themselves dropped into a

\footnotetext{
${ }^{148}$ Diana Williamson, 'Notes From the Scullery - Whose Rights? Our Rights! Well, Not Really...', Illinois Gender Advocates Newsletter, January 2003, 3-4.

${ }^{149}$ Ltttleton v Prange, 9 SW 3d 223 (Tex App - San Antonio 1999, pet. denied), cert. denied, 535 US 872 (2000).

${ }^{150}$ The most authoritative American statement on transsexual identity and marriage had come from the Appellate Division of the Superior Court of New Jersey in 1976 via M.T. v J.T.

${ }^{151}$ The Texas Attorney General had garnished Mrs. Littleton's income to satisfy the child support obligation of Mr. Littleton from a previous marriage, thereby recognising Christie Lee's and Jonathan's marriage. Petition for Writ of Certiorari, Ltttleton v Prange, 535 US 872 (2000) (No. 00-25).

${ }^{152}$ Littleton, 9 SW 3d, 226. Other cases had cited DOMA, but in the context of unmarried gay couples seeking legal recognition of their relationships. See In re Allen, 186 BR 769 (ND Ga, 1995).

${ }^{153}$ Baz Luhrman, 'Everybody's Free (to Wear Sunscreen)', on, Something For Everybody (1999).

${ }^{154}$ Katrina C Rose, 'The Transsexual and the Damage Done: The Fourth Court of Appeals Opens PanDOMA's Box By Closing the Door on Transsexuals' Right to Marry' (1999/2000) 9 Law \& Sexuality 1, 129 (noting how few Texas transsexuals had heard of the case until after it had been heard by the San Antonio Court of Appeals). Here, it must be noted that in 'Transsexual and the Damage Done', I took the position that the decision against the transsexual surviving spouse in Littleton may well have been proper, though only because of the specific facts of her case. Although in the years since writing that
} 
battle that not only had not been of their making but was one that they had had no input in whatsoever: the modern push for same-sex marriage.

After Littleton came In re Gardiner, in which, after an extremely enlightened opinion from an intermediate appellate court, ${ }^{155}$ the Kansas Supreme Court invoked not one but two Kansas state DOMAs in obliterating the womanhood (in Kansas at least) of Park University Professor J'Noel Gardiner, a Wisconsin-born male-tofemale transsexual. ${ }^{156}$

By far the more significant of the two is the one enacted in 1980, the end result of three successive legislative sessions (from 1975 to 1980) of attempts to pass antimarriage legislation. The complete entry in the minutes of the 21 January 1976 Senate Judiciary Committee hearing, quoted in part in the Gardiner Court of Appeals opinion, ${ }^{157}$ reads:

Senator Pomeroy appeared on S.B. 350 which would amend K.S.A. 23101 to provide that marriage shall be entered into by two parties of the opposite sex. The bill would also amend K.S.A. 23-106 so that a probate judge could not issue a marriage license to two parties of the same sex. This bill would affirm the traditional view of marriage.

Senator Storey moved to recommend this bill favourably for passage. Senator Talkington seconded this motion which was approved by a voice vote of the Committee. $^{158}$

The first paragraph corresponds to the supplemental information entry on S.B. $350 .{ }^{159}$ The provision of S.B. 350 which is critical to this discussion was slightly different, though not substantively, than that which ultimately became law in 1980 . S.B. 350 would have altered Section 23-101 to read 'The marriage contract is to be

article my stance has become a bit less harsh (in part because of further analysis of the opinion and coming to the conclusion that the general anti-transition-recognition language in it is even farther offbase than I'd asserted in 1999), it is still my view that, because of the facts of Mrs. Littleton's case and because of the pathetic job of presenting the case that occurred up through the intermediate appellate level (my frequent co-authors, Alyson Meiselman and Phyllis Frye, took over representation of Mrs. Littleton after the decision which yielded the oft-cited published opinion), a legitimate opinion could have been issued by the San Antonio Court of Appeals upholding the summary judgment against her but nevertheless respecting transsexuals' rights in general or making plain that the court was taking no position on transsexuals' rights in general.

15522 P 3d 1086 (Kan App, 2001).

${ }^{156} 42$ P 3d 120 (Kan, 2002).

${ }^{157}$ Gardiner, $22 \mathrm{P} 3 \mathrm{~d}, 1093$.

${ }^{158}$ Minutes of the Kansas Senate Committee on Judiciary, 2 (21 January 1976).

159 Brief of Bill:

SB 350 would amend K.S.A. 23-101 to provide that marriage shall be entered into by two parties of the opposite sex. The bill would also amend K.S.A. 23-106 so that a probate judge Background:

could not issue a marriage license to two parties of the same sex.

This bill would affirm the traditional view of marriage.

1975 KAN. S.B. 350, Supplemental Information (italics in original). 
considered in law as a civil contract, entered into between two parties of the opposite sex.... 160 The same language appeared in the substantively similar bill from the 1977 Session, S.B. 309. ${ }^{161}$ Committee amendments occurred, though not affecting the 'opposite sex' clause.

Still, the 1977 bill did not pass. 1980 Senate Bill 609, as proposed by, among others, Senator Donald Allegrucci, was titled as:

An act establishing the family and children trust fund; providing for the deposit of certain fees in such fund; increasing the marriage license registration fee; amending K.S.A. 1979 Supp. 23-108, 23-109 and 23-110 and repealing the existing sections. ${ }^{162}$

This bill contained no mention of same-sex marriage, although the manner in which it did touch upon marriage - the increase of the license fee - did garner significant attention. ${ }^{163}$ By far, however, the main issue when the bill was before the Senate Judiciary Committee on 21 February and 25 February was the trust fund aspect of the bill. In fact, in the entries on the minutes from both hearings refers to S.B. 609 with the heading 'Family and Children Trust Fund Established.' 164

The 21 February hearing was devoted entirely to S.B. 609 and, although a letter was submitted from the Kansas Catholic Conference expressing concern over the bill's 'possible extension into the field of family planning, ${ }^{165}$ the only apparent testimony involving marriage per se appears to have come from Dr. Kenneth Mauldin, who, according to the minutes appearing on his own behalf as a pastor, testified that he has a philosophical problem with the bill. He stated that he is not opposed to the programs the bill is designed to fund; he simply questions whether this is the right way to raise these funds. He stated that whenever a fee is charged that is more than the actual cost of administering the marriage license program, the state is in effect taxing marriage. He stated he has concerns about keeping church and state separate, and when a tax is placed on marriage, he fears that line might be crossed. ${ }^{166}$

\footnotetext{
${ }^{160} 1975$ KAN. S.B. $350, \S 1$.

${ }^{161} 1977$ KAN. S.B. $309, \S 1$.

1621980 KAN. S.B. 609, Preamble.

${ }^{163}$ In light of the purported 'defense of marriage' slant given to anti-same-sex marriage bills and statutes in the 1990's, the remark of S.B. 609 supporter Sen. Frank Smith, described by the Topeka CapitolJournal as a bachelor, a might seem ironic. In response to another senator's question as to whether the marriage license fee increase aspect of the bill would "lead more people to live in sin and not get married, Smith said, "Anything that would make marriage prohibitive is fine with me." 'Senate Approves \$7 Marriage License Fee Hike', Topeka Capitol-Journal, 5 March 1980, 11.

${ }^{164}$ Minutes of the Kansas Senate Committee on Judiciary, 1 (21 February 1980); Minutes of the Kansas Senate Committee on Judiciary, 3 (25 February 1980).

${ }^{165}$ Letter from Vincent DeCoursey, Executive Director, Kansas Catholic Conference to Senator Elwaine F. Pomeroy (20 February 1980).

${ }^{166}$ Minutes of the Kansas Senate Committee on Judiciary, 2-3 (21 February 1980).
} 
Eighteen people spoke in favour of the bill, either personally or on behalf of organisations. ${ }^{167}$ The Kansas Women's Political Caucus was represented by Kathleen Sebelius, who asserted that the raising of the marriage license fee to $\$ 17.00$ would not make it 'prohibitive.' 168 After further discussion and amendments, on February $25^{\text {th }}$ the Committee favourably reported the bill to the full Senate ${ }^{169}$ - which is where the damage would occur.

On 4 March, while S.B. 609 was under consideration by the Committee of the Whole, Senator Pomeroy, the author of the 1975 and 1977 stand-alone bills, moved to add a section to the bill which would amend Section 23-101 to read: 'The marriage contract is to be considered in law as a civil contract between two parties who are of opposite sex..., 170 According to the Kansas City Times this 'was adopted without discussion.' $17 i$ The House Judiciary Committee minutes of 25 March and 26 March dealing with the amended bill make no mention of Pomeroy's 'opposite sex' clause. ${ }^{172}$ Considering the lack of discussion of the amendment on the Senate floor, it is by no means clear whether the bill's proponents were even aware of the change, much less overtly supportive of it. ${ }^{173}$

In 1980, Senator Donald Allegrucci was a co-author of the Pomeroy-amended bill. He was a member of the Judiciary Committee that considered Pomeroy's standalone bill and the 1977 bill.

The author of the 2002 anti-recognition Gardiner opinion? Justice Donald Allegrucci.

His having resorted to a 1970 dictionary definition in $2002^{174}$ in order define what the Legislature meant in 1980 is deeply disturbing. There simply was no need to so resort. Allegrucci had a hand in all three attempts at adding that anti-marriage provision to Kansas law. There can be no conclusion other than that he knew exactly what had been intended by the clause, for every bit of legislative history points only to an intent to prohibit homosexuals from attaining legal status for samesex unions. Beyond being devoid of logic (by virtue of being out of date even in

\footnotetext{
${ }^{167}$ Minutes of the Kansas Senate Committee on Judiciary, 1-3 (21 February 1980).

${ }^{168}$ Minutes of the Kansas Senate Committee on Judiciary, 2 (21 February 1980) (entry regarding testimony of Kathleen Sebelius). Several months after the second Gardiner opinion, Sebelius was elected governor of Kansas. 'Sebelius, Graves to Discuss State Budget Shortfall', Topeka Capitol-Journal, 6 November 2002, <http://cjonline.com/stories/110602/bre_sebelius.shtml>.

${ }^{169}$ Minutes of the Kansas Senate Committee on Judiciary, 3 (25 February 1980).

${ }^{170} 1980$ Kansas Journal of the Senate, 1011 (emphasis added).

171 'Angling for Support', Kansas City Times, 5 March 1980. The Topeka Capitol-Journal's account made no mention of what, if any, discussion Pomeroy's amendment received. 'Senate Approves \$7 Marriage License Fee Hike', Topeka Capitol-Journal, 5 March 1980, 11.

${ }^{172}$ Minutes of the Kansas House Committee on Judiciary, 1-2 (25 March 1980); Minutes of the Kansas House Committee on Judiciary, 2 (26 March 1980).

${ }^{173}$ Much of the submitted material is almost identical to that submitted to the Senate committee a month earlier.

${ }^{174}$ Gardiner, 42 P3d, 135.
} 
1980), utilising a 1970 dictionary in 2002 to clarify what the legislature could have done then is an egregiously unethical second bite ${ }^{175}$ at the legislative apple.

Of course, it stands as a shining example of what can happen once anti-same-sex marriage laws become enshrined in the statute books: judges, claiming with straight faces to be strict constructionists, will legislate anti-transsexual clauses clearly, per the historical record, never envisioned by the legislature onto these laws.

Laws enacted against gays' quest for same-sex marriage.

Transsexuals pay the price.

\section{(b) 2003: In re Nash and Barr}

Ohio's courts have a history of producing ridiculously transphobic opinions in cases involving issues of transsexual identity. ${ }^{176}$ Even more ridiculous is the weight afforded the various opinions. A 1976 intermediate appellate court opinion dismissively turned aside a request by a non-Ohio-born transsexual to secure recognition of gender transition. ${ }^{177}$ Despite the fact that it could arguably be used to support transition non-recognition in the state, that unpublished decision, Maxey $v$ Appel, has been all but ignored.

A quarter-century after that decision, the Ohio Supreme Court issued an exceedingly short opinion recognising the right of a pre-operative transsexual to secure a name change. ${ }^{178}$ The brevity of that decision was the result of it simply being an adoption of another opinion, issued a few weeks earlier, where the issue had been the ability of same-sex couples to establish a last name in common - and it obscures the depth of transphobia in the lower court opinions, which had all held against MTF transsexual Susan Maloney on overtly religious grounds and nebulous concepts of public policy ${ }^{179}$

In between some early cross-dressing cases (which mostly had TG-positive outcomes) and recent name-change cases (also positive) was In re Ladrach, a 1987 probate court opinion which had approved of a name change for a MTF but ruled that Ohio did not recognise the ability of transsexuals to conform their birth certificates to post-transition reality. ${ }^{180}$ Despite the fact that this opinion is from the

\footnotetext{
${ }^{175}$ When taking into account the 1975 and 1977 bills, perhaps fourth bite actually would be more appropriate.

See In re Maloney, No. CA2000-08-168, 2001 Ohio App. LEXIS 3550 (Ohio Ct App, 13 August 2001); and In re Ladrach, above n 40. There were a handful of favourable early 1970's opinions regarding the enforceability of cross-dressing ordinances. City of Columbus v Rogers, 324 NE 2d 563 (Ohio, 1975); City of Cincinnati v Adams, 330 NE 2d 463 (Ohio Mun Ct Hamilton County, 1974); and, City of Columbus v Zanders, 266 NE 2d 602 (Ohio Mun Ct Franklin County, 1970).

${ }^{177}$ Maxey $v$ Appel, No. 34558 (Ohio Ct App. $8^{\text {th }}$ Dist, 5 February 1976).

${ }^{178}$ In re Maloney, 774 NE 2d 239 (Ohio, 2002).

${ }^{179}$ See Katrina C. Rose, 'Three Names in Ohio: In re Bicknell, In re Maloney and Hope For Recognition that the Gay-Transgender Twain Has Met', (2002) 25 Thomas Jefferson Law Review 89, 117-32.

${ }^{180} 513$ NE 2d, 829.
} 
lowest level of court in the state - a level of court that, in most other states, would not even be allowed to issue published opinions - Ladrach is regularly afforded more legitimacy than conflicting (and far better-reasoned) appellate authority. ${ }^{181}$

Such was the situation when Jacob Nash and Erin Barr sought a marriage license.

In August 2002 (around the same time that the Ohio Supreme Court had decided In re Maloney, the transsexual name change case), Nash, a FTM transsexual, and Barr, a non-transsexual female, sought a marriage license in Trumbull County, Ohio. Although Nash was born in Massachusetts and effectuated an updating of his birth certificate pursuant to that state's transsexual birth certificate statute in April 2002, he had applied for and received a name change in Tumbull County, Ohio in $2000 .{ }^{182}$ The paperwork connected with the name change had included the pre-transition version of his birth certificate - and that 2000 paperwork was reviewed at the time of the 2002 marriage application. Additionally, the marriage application did not include mention of Nash's pre-transition marriage to a man - although a subsequent amended application did. ${ }^{183} \mathrm{~A}$ subsequent separate application (which also did include disclosure of the pre-transition marriage), resulted in a hearing in which Nash was questioned by the probate court regarding his SRS. On advice of his counsel, Nash refused to answer, asserting that the conformed post-transition Massachusetts birth certificate offered all necessary answers to questions regarding his sex. ${ }^{184}$

Both applications were denied - and the couple appealed both denials, asserting the following issues:

The trial court erred in holding appellant's application for a marriage license to a higher evidentiary standard than the standard to which it holds other applications, thereby denying appellants equal protection of the laws under the United States Constitution and the Constitution of the State of Ohio

and

The trial court erred in refusing to give full faith and credit to Jacob Nash's valid, corrected Massachusetts birth certificate when he presented it in support of appellants' application for a marriage license. ${ }^{185}$

A 2-1 majority of the Court of Appeals, with the lead opinion authored by Dianne Grendell, took only eight paragraphs to dispose of the first point, devoting most of the opinion to the second.

\footnotetext{
${ }^{181}$ See Littleton, 9 SW 3d at 228-29; and Gardiner, 42 P 3d, 130-31.

${ }^{182}$ Nash and Barr, *1.

${ }^{183}$ Ibid.

${ }^{184}$ Ibid. *2.

${ }^{185}$ Ibid.
} 
Noteworthy, though, is that in declaring that the Ohio marriage statute utilised to deny the license (based on the non-disclosure of the marriage and on the question of Nash's sex not being resolved to the trial court's satisfaction) is, as applied to the couple, a 'reasonable regulation that does not significantly interfere with decisions to enter into the marital relationship and, thus, for purposes of equal protection analysis, the statute is entitled to examination under the rational basis standard,' following that sentiment with 'States possess a legitimate interest in protecting the institute of marriage within its borders,' Grendell cited to the federal DOMA. ${ }^{186}$

Even more interesting was the manner in which she concluded that Ohio did not need to give any legal effect to Nash's post-transition birth certificate, relying on general evidentiary rules to construct an illusion of immateriality - not only regarding the conformed sex designation on Nash's birth certificate but also, and far more disturbingly, the entire existence of transsexual birth certificate statutes. While acknowledging the existence of the U.S. Constitution's mandate that 'Full Faith and Credit shall be given in each State to the public Acts, Records, and judicial Proceedings of every other State, ${ }^{187}$ Grendell went on to note federal statutes which purport to limit that language by declaring that such acts, records and proceedings are to be given the effect that they have in the state from which they originate. This would seem not to be a problem regarding Nash's birth certificate - except that Grendell goes on to cite Massachusetts evidence law as viewing birth certificates to be 'prima facie evidence of the facts recorded' therein, meaning that evidence can be presented to rebut the presumption established by the document. Then it would be up to the court to make a decision based on all evidence. According to Grendell: In this case, the amended birth certificate submitted by Nash as evidence of his sex was rebutted by the evidence already in possession of the trial court, to wit, Nash's original birth certificate designating Nash's sex as female. Thus, the trial court gave Nash's amended Massachusetts birth certificate the proper full faith and credit, prima facie evidence of the facts contained therein. ${ }^{188}$

While this may seem like a logical application of evidentiary principles, it is actually a ruse - one which totally ignores an aspect of law which anti-GLBT courts are all too eager to cite against GLBT people: public policy.

Unlike one of the previous anti-transsexual Ohio opinions, the 1987 Ladrach probate court opinion - in which the authoring judge clearly expresses the view that a state which enacts a transsexual birth certificate statute is stating that someone who undergoes SRS and conforms his or her birth certificate to the post-transition sex designation may marry as a member of that post-transition sex ${ }^{189}$ - Grendell showed an absolute lack of capability of believing that there could be a public policy anywhere in favour of transition recognition: a policy evidenced by the very fact that

\footnotetext{
186 Ibid. *3

${ }^{187}$ US Const, Art IV, $§ 1$.

${ }^{188}$ Nash and Barr, *5.

${ }^{189}$ Ladrach, 513 NE 2d, 531.
} 
the legislature of a given state has recognised the medical and social reality of transsexualism via enactment of a statute allowing transsexuals to conform their birth certificates to the reality of their post-transition existence. Her creation of a 'prima facie evidence' loophole is one which would allow any judge or administrative official to manufacture an exception in every case involving any transsexual, thereby swallowing any and all logical conclusions mandated by the existence of legislative recognition of transsexualism.

Nevertheless, Grendell's reliance on 'public policy,' might possibly have had merit if Ohio had statutes which were diametrically opposed to - and, therefore, presumably incompatible with - recognition of gender transition. However, Ohio had (and still has) no statute with transsexual-specific wording purporting to legislate against transsexualism $^{190}$ - and, despite the notorious Maloney and Ladrach lower court opinions, the overall state of authoritative Ohio decisional law is mixed, being arguably at worst only slightly unfavourable to recognition of transsexual identity though, arguably, more in favour of it. ${ }^{191}$ As have other courts, she referred to 'public policy' emanating from Ohio's non-transsexual-specific birth certificate statute as allowing only 'Errors/Mistakes' on birth certificates to be dealt with postissuance.

Aside from the fact that this ignores the science of transsexualism, which has progressed to the point where conforming of a sex designation to post-transition reality must be objectively recognised as indeed correcting an error, it also ignores the fact that the anti-transsexual spin put on Ohio's birth certificate statutes was created by judges - and, as such, can be dispensed with by judges as having been supplanted or having been wrong from the start. For, while it is true that the Ohio Legislature has never enacted positive transsexual-specific language (with the only such bill of which I am aware, almost a decade pre-Ladrach in 1979, having passed in the House only to die in the Senate) ${ }^{192}$, it had also never seen fit to enact negative transsexual-specific language to ensure that no other court might come to a different conclusion than Ladrach.

Unfortunately, Nash \& Barr was not appealed. Consequently, the day when legitimate gender transition analysis might emerge from an Ohio appellate court is still not in sight.

\section{From DOMA to the FMA}

The legislative history of DOMA was complete in 1996, but that of the FMA (and new state DOMAs) is ongoing. Such trans-absence as has been demonstrated above would, in any other context, be decidedly negative for transsexuals. However, this

\footnotetext{
${ }^{190}$ Only Tennessee has such a statute. TENN. CODE ANN. § 68-3-203 (d) (1999).

${ }^{191}$ Two pro-transgender decisions, a quarter-century apart. See Maloney, 774 NE 2d, 239; and Rogers, 324 NE 2d, 565-66 (the Rogers opinion does not indicate if the defendant who had been charged with cross-dressing was a transsexual).

1921979 OHIO H.B. 750.
} 
absence in this context should be, at least in retrospect, regarded as a positive - a mandate for such legislation not to be construed against transsexuals, whatever the initial inclination might be of those in a position to construe them against transsexuals.

But, if all of that is not enough, once the FMA has become part of the U.S. Constitution, another nugget of history might seem useful to have to combat it - perhaps something akin to Louisiana State Sen. John Hainkel's connection to his state's transsexual birth certificate statute 36 years prior to his involvement with his state's DOMA. Of course, as noted in Part II, there was no Federal Gender Transition Recognition Act and, even if there was, no one from the Congress of 1948 is around to form a Hainkel-esque nexus.

Or is there?

No, there indeed is not an FGTRA, but a number of FMA proponents began their political lives in state legislatures. One (of many) is the aforementioned Colorado Rep. Marilyn Musgrave. ${ }^{193}$ Another is one of her state's U.S. Senators, Wayne Allard - who also is one of the sponsors of the FMA. Twenty years ago, as a Colorado state senator, Allard was a co-author of the bill which, when it took effect, established Colorado's transsexual birth certificate statute. ${ }^{194}$

Although that 1984 statute is not of the clear, stand-alone variety ${ }^{195}$ that the 1968 Louisiana statute typifies, and although I have been unable to find 1984 Colorado citations to the type of trans-positive colloquy that occurred in Louisiana in 1968, the principle of the 'Hainkel Connection' should apply: even if Allard now asserts that anti-same-sex marriage language that does not specifically deal with transsexual marriages wipes such marriages out nevertheless via a so-called 'ordinary, common meaning, ${ }^{196}$ it cannot be contended that Allard himself had no knowledge of more complicated concepts - concepts which must be imported to such a sweeping proposal as a national ban on same-sex marriage.

Still, the question remains: Will all of the above save transsexuals when the FMA becomes part of the constitution?

But, what also must be asked is: Why was such a positive body of queer legal development forcibly tied down to a railroad track with both the DOMA and FMA locomotives speeding toward it? Part VI may offer some insight into this. How-

\footnotetext{
193 'Representative Marilyn N. Musgrave (CO)', PROJECT VOTE SMART, <http://www.votesmart.org/bio.php?can_id=BS020598> (last visited 26 September 2004).

1941984 COLO. S.B. 142. A few votes were cast against the bill in the Colorado House, but it still passed overwhelmingly: 55-7 (3 excused absent). 1984 Colorado House Journal 893 (15 March 1984). I have been unable to locate the Senate vote totals (For the record, the University of Iowa Law Library is one of the best in the nation, particularly as to state law materials. However, for whatever reason, it did not end up with a copy of the 1984 Colorado Senate Journal.)

1951984 COLO. LAWS Ch. 206, § 12.

${ }^{196}$ Gardiner, 42 P3d, 129 (quoting Ulane, 742 F 2d, 1085).
} 
ever, before that, it will pay to fully explore all of what has been tied down to the railroad track - and it may not be simply transsexuals' identity and marital rights.

\section{EMPLOYMENT LAW}

When it comes to employment discrimination protection, most Americans think of Title VII. Transsexuals are no different (though we also think of ENDA, but for political reasons.) However, as Stephanie Belser observed in 1998, perhaps the phrase 'don't make a federal case of it' should be heeded occasionally. ${ }^{197}$

\section{A Title VII and Oiler v Winn-Dixie}

When he was not at work with the non-fictional grocery store chain Winn-Dixie, Peter Oiler, a married, heterosexual male, would go out cross dressed in public approximately one to three times per month. Judge Lance Africk described Oiler thus:

He shaves his face, arms, hands, and legs. He wears women's underwear and bras and he uses silicone prostheses to enlarge his breasts. When he is cross dressed as a woman, he adopts a female persona and he uses the name "Donna". 198

He had been cross-dressing in public since 1996.

On October 29, 1999, [Oiler] told Gregg Miles, a Winn-Dixie supervisor, that he was transgendered. He explained that he was not a transsexual and that he did not intend to become a woman. However, he told Miles that for a number of years he had been appearing in public at restaurants and clubs while cross dressed. He told Miles that while he was cross dressed, he assumed the female role of "Donna". He asked whether he would be terminated if Michael Istre, the president of Winn Dixie Louisiana, Inc., ever saw plaintiff cross dressed as a woman. ${ }^{199}$

Miles had a private meeting with Istre that same day in which Miles told Istre that Oiler was transgendered and had been appearing in public cross dressed as a woman. Istre subsequently contacted Winn-Dixie's counsel for legal advice. ${ }^{200}$ Istre and Miles made the decision to terminate Oiler's employment with Winn-Dixie, several times asking Oiler to resign. On January 5, 2000, when Oiler did not resign voluntarily, Winn-Dixie fired him. ${ }^{201}$ According to Africk:

\footnotetext{
${ }^{197}$ Stephanie Belser, 'Don't Make a Federal Case of it: Gender Outlaws and Employment Discrimination' (1998) 2 South Texas Civil Liberties Journal 17, 33.

198 Oiler, 2002 U.S. Dist. LEXIS 17417, * 6 (footnotes omitted).

${ }^{199}$ Ibid *7-8

${ }^{200}$ Ibid *8.

${ }^{201}$ Ibid *9.
} 
The reason [Oiler] was terminated was because he publicly adopted a female persona and publicly cross dressed as a woman. Specifically, Istre and Miles, acting for Winn-Dixie, terminated Oiler because of his lifestyle, i.e., [Oiler] publicly cross dressed for several years by going to restaurants and clubs where he presented himself as "Donna", a woman. Istre and Miles believed that if [Oiler] were recognised by Winn-Dixie customers as a cross dresser, the customers, particularly those in Jefferson Parish where [Oiler] worked, would disapprove of the [Oiler's] lifestyle. Istre and Miles thought that if Winn-Dixie's customers learned of [Oiler's] lifestyle, i.e., that he regularly cross dressed and impersonated a woman in public, they would shop elsewhere and Winn-Dixie would lose business. [Oiler] did not cross-dress at work and he was not terminated because he violated any Winn-Dixie on-duty dress code. He was never told by any Winn-Dixie manager that he was being terminated for appearing or acting effeminate at work, i.e., for having effeminate mannerisms or a high voice. Nor did any Winn-Dixie manager ever tell [Oiler] that he did not fit a male stereotype or assign him work that stereotypically would be performed by a female. ${ }^{202}$

Precisely how big the grain of salt that the last two sentences should be taken with, is for the reader to decide.

Oiler sued pursuant to Title VII and, in an unusual turn for a transgendered Title VII plaintiff, was the moving party on a summary judgment motion. Of course, Winn-Dixie has its own motion.

When Africk began his discussion of Title VII case law, unsurprisingly, Africk led with Ulan and added mention of seemingly all of the anti-transsexual Title VII decisions. $^{203}$ Of course, of those, he didn't bother to mention that one had been transsexual-positive, though on a Rehabilitation Act claim. ${ }^{204}$ Nevertheless, Africk went on to produce his own version of why a transgendered person should lose a Title VII claim.

Despite the fact that the number of persons publicly acknowledging sexual orientation or gender or sexual identity issues has increased exponentially since the passage of Title VII, the meaning of the word "sex" in Title VII has never been clarified legislatively. From 1981 through 2001, thirty-one proposed bills have been introduced in the United States Senate and the House of Representatives which

\footnotetext{
${ }^{202}$ Ibid. *9-10.

${ }^{203}$ Ibid. *20, n 51 (citing Holloway v Arthur Andersen \& Co., 566 F 2d 659 (9th Cir, 1977); Sommers v Budget Marketing, Inc., 667 F 2d 748 (8th Cir, 1982); Dobre v National R.R. Passenger Corp., 850 F Supp 284 (ED Pa, 1993); Powell v Read's, Inc., 436 F Supp 369 (ED Md, 1977); Voyle v Ralph K. Davies Medical Center, 403 F Supp 456 (ND Cal, 1975), aff'd, 570 F 2d 354 (9th Cir, 1978)(Table, No. 75-3808); Doe v United States Postal Service, 1985 U.S. Dist. LEXIS 18959 (D DC, 1985); Emanuelle v United States Tobacco Co., Inc., 1987 U.S. Dist. LEXIS 9790 (ND Ill, 1987), aff'd, 886 F.2d 332 (7th Cir, 1989)(Table, No. 87-2785); James v Ranch Mart Hardware, Inc., 1994 U.S. Dist. LEXIS 19102 (D Kan, 1994); and, Rentos v Oce-Office Systems, 1996 U.S. Dist. LEXIS 19060 (SD NY, 1996)). ${ }^{204}$ Doe v U.S.P.S., No. 84-3296, 1985 U.S. Dist. LEXIS 18959 (D DC, 12 June 1985).
} 
have attempted to amend Title VII and prohibit employment discrimination on the basis of affectional or sexual orientation. None have passed.

In contrast to the numerous failed attempts by Congress to include affectional or sexual orientation within Title VII's ambit, neither plaintiff nor defendant can point to any attempts by Congress to amend Title VII in order to clarify that discrimination on the basis of gender or sexual identity disorders is prohibited. Neither party has identified any specific legislative history evidencing Congressional intent to ban discrimination based upon sexual or gender identity disorders. ${ }^{205}$

Included therein was the denigration of the attempt to use Price Waterhouse to get out from under the two paragraphs quoted immediately above.

The Court in Price Waterhouse implied that a suit alleging harassment or disparate treatment based upon nonconformity with sexual stereotypes is cognizable under Title VII as discrimination because of sex. This theory would not bootstrap protection for sexual orientation into Title VII because not all homosexual men are stereotypically feminine, and not all heterosexual men are stereotypically masculine. But, under this theory, relief would be available for discrimination based upon sexual stereotypes. $^{206}$

Interestingly, then, in a footnote, Africk stated, 'Long after Price Waterhouse was decided, courts have continued to hold that discrimination on the basis of sexual preference or orientation is not actionable under Title VII because it is not discrimination based on a person's "sex." 207 However, he did not see fit to mention the Price Waterhouse-esque cases that had gone against the Ulane mindset - cases such as Schwenk v Hartford and Rosa v Park West Bank. Perhaps he could have woven a rationale to support his view in spite of these decisions. ${ }^{208}$ But, their absence renders Oiler suspect at best.

[Oiler's] actions are not akin to the behaviour of plaintiff in Price Waterhouse. The plaintiff in that case may not have behaved as the partners thought a woman should have, but she never pretended to be a man or adopted a masculine persona.

\footnotetext{
205 Oiler, 23.

${ }^{206}$ Ibid *27 (quoting Simonton v Runyon, 232 F.3d 33, 38 n.59 (2nd Cir. 2000)).

${ }^{207}$ Ibid $* 27$, n. 59

${ }^{208} \mathrm{He}$ quickly rationalised his way out of Nichols v Azteca Restaurant Enterprises, Inc., 256 F 3d 864 (9 $9^{\text {th }}$ Cir, 2001). Ibid. *28, n. 60 .
} 
This is not just a matter of an employee of one sex exhibiting characteristics associated with the opposite sex. This is a matter of a person of one sex assuming the role of a person of the opposite sex. After a review of the legislative history of Title VII and the authorities interpreting the statute, the Court agrees with Ulane and its progeny that Title VII prohibits employment discrimination on the basis of sex, i.e., biological sex. While Title VII's prohibition of discrimination on the basis of sex includes sexual stereotypes, the phrase "sex" has not been interpreted to include sexual identity or gender identity disorders. ${ }^{209}$

The Oiler decision was never appealed (not that the ultra-conservative Fifth Circuit would have been any more likely to acknowledge the existence of the case law that Africk ignored.) Still, the end result? So much for a Price Waterhouse path to transgender anti-discrimination protection - at least in Louisiana.

\section{B Louisiana Law}

Most states now have their own laws prohibiting employment discrimination based on sex and other aspects of personal existence, with many, though by no means all, filling gaps left by Title VII and other federal statutes. ${ }^{210}$ Some state laws predate the Civil Rights Act of 1964 and others were enacted afterward. At the time of the enactment of the Civil Rights Act, Louisiana labour law contained an entire series of statutes under the heading "Female Persons." 11 For example, one mandated that No female shall be employed in any mine, packing house, bowling alley, bootblack establishment, in the distribution of merchandise, in or about any place of amusement where intoxicating liquors are made or sold ... for more than nine hours in any one day or fifty-four hours in any one week. ${ }^{212}$

Ostensibly for the protection of women, the statutes had little, or nothing, to do with equality (with one commanding no employment of "women and girls" under conditions 'detrimental to their health or morals" ${ }^{213}$ ), and many remained on the books until $1976 .^{214}$

Furthermore, not until 1983, during the interregnum between Edwin Edwards' second and third terms as Louisiana's governor, did the state put into place somewhat of a proper state complement to Title VII. According to a Tulane Law Review

\footnotetext{
${ }^{209}$ Ibid. *29-30.

${ }^{210}$ As even an episode of the animated television series King of the Hill demonstrated a few years ago, the heavyweight federal employment anti-discrimination statutes only apply to employers with 15 or more employees. FOX Television (USA), King of the Hill, 'Junkie Business' (26 April 1998). Some, though not all, states have a lower threshold.

${ }^{211}$ LA. REV STAT., tit. 23, Part IV (West 1964), repealed, 1976 LA. ACTS. Ch. 24.

21223 LA. REV STAT. \$ 311 (West 1964), repealed, 1976 LA. ACTS. Ch. 24.

${ }^{213} 23$ LA. REV STAT. $\$ 353$ (West 1964), repealed, 1976 LA. ACTS. Ch. 24.

${ }^{214}$ Joel William Friedman, 'Fair Employment Legislation in Louisiana: A Critique of the 1983 Act and a Proposed Substitute Statute’ (1983) 58 Tulane Law Review 444.
} 
article at the time by Professor Joel Friedman, 43 states, D.C. and Puerto Rico had such a complementary set-up by $1983 .^{215}$ Six others, including Louisiana, had a 'patchwork of independent statutes' which did various things; Louisiana's addressing only age and 'handicap. ${ }^{216}$ The ever-regressive Alabama, not surprisingly, had no protection for non-government employment settings and precious little for government employment. ${ }^{217}$

On the last day of its regular 1983 session, however, the Louisiana Legislature made its own attempt at enacting a broad-based equal employment opportunity law and passed a statute prohibiting intentional discrimination in employment on account of race, colour, religion, sex, or national origin. $^{218}$

There was no sexual orientation - either with the Minnesota (or, more accurately as to what was in force then, Minneapolis) definition or with the transphobic definition utilised in Maryland ${ }^{219}$ and New York. ${ }^{20}$ And, there was no stand-alone gender identity category.

Yet, a very strong case could be made that if Peter Oiler was not a cross dresser but, instead, a transsexual and if he had brought his case against Winn-Dixie under Louisiana state law rather than federal law, then the same reasoning which was used to reject his Title VII federal court case would have mandated a more favourable result for him under state law.

\section{Unification?}

This is where the fiction of Part II proves its usefulness as an analogy. What if Congress actually had passed a Federal Gender Transition Recognition Act at some point before it passed Title VII? Well, among other things, ${ }^{221}$ there could be absolutely no validity to any Holloway-Sommers-Ulane-esque absolutist contention that Congress had no intention of encompassing 'because of change of sex' in the phrase 'because of sex' that was tossed into Title VII by anti-equality forces who simply were trying to kill the bill. ${ }^{222}$ There would be a history of Congress addressing the subject of transsexualism, making it rational, even mandatory, to presume that in the future when it addressed "sex," something beyond a non-transsexual-inclusive, corporate-authored dictionary definition of "sex" would be what was meant.

\footnotetext{
${ }^{215}$ Ibid 444.

${ }^{216}$ Ibid 445.

${ }^{217}$ Ibid.

${ }^{218}$ Ibid.

${ }^{219} 2001$ MD. LAWS Ch. 340, codified at 49B MD. ANN. CODE § 15 (j) (2003).

${ }^{220} 2002$ N.Y. LAWS Ch. 2, codified at N.Y. EXEC. LAW § 292 (27) (2004).

${ }^{221}$ What immediately comes to mind is that it would certainly undermine any assertion that any religionist might one day make to the effect that the federal DOMA might actually have been intended to undermine the gender identities of transsexuals.

${ }^{222}$ See Miller, above n 36.
} 


\section{Alas, there is no FGTRA.}

However, as we've seen, by 1983 Louisiana had had a transsexual-specific ${ }^{223}$ birth certificate modification statute on its books - for a decade and a half. The flipside of the anti-transsexual reasoning of the Holloway line of cases dictates that there can be no validity to any contention that, after June of 1968, the Louisiana Legislature had nothing more than the so-called traditional (read: not inclusive of transsexuals ${ }^{224}$ ) concept of sex whenever it included the word "sex" in a piece of legislation. And, logically, that would have to include employment antidiscrimination legislation enacted by the Louisiana Legislature in 1983 - with or without any evidence of any mention of transsexuals during debate on the measure.

Of course, even if this is recognised as being viable by Louisiana's courts, there are significant gaps - and there will be others. Post-Oiler $v$ Winn-Dixie, there would appear to be no protection for non-transsexual, non-intersexed transgendered people at all in Louisiana - at least outside of New Orleans, which has a transgenderinclusive civil rights ordinance. ${ }^{225}$ And, even beyond that gap, even if my theory is recognised there still would be no concrete protection for any transgendered person with respect to federal employment even if the currently-worded ENDA proposal becomes law. ${ }^{226}$

Is my theory a step in the right direction?

Yes - particularly with respect to recognising the full, penumbral vitality of existing pro-transsexual legislation.

Is my theory enough?

Certainly not - and with the anti-gay marriage backlash barrelling toward us, it may be an incredibly endangered species.

\footnotetext{
${ }^{223}$ And intersexual-inclusive for that matter. 40 LA. REV. STAT $\$ 62$ (C) ('The court shall require such proof as it deems necessary to be convinced that the petitioner was properly diagnosed as a transsexual or pseudo-hermaphrodite....') (emphasis added).

${ }^{224}$ A debate that I will not include here is whether even this 'traditional' definition actually does encompass 'change of sex' in spite of what agenda-minded judges have rottenly accepted from far-too-many defendants. However I will remind the reader that dictionary definitions cited in such cases come not from itinerant scholars such as Samuel Johnson but from corporations that have their own agendas. For instance, Black's Law Dictionary, a West publication, was cited against J'Noel Gardiner just a few months after West Group had bafflingly prevailed in a transgender discrimination case brought pursuant to the Minnesota Human Rights Act. Gardiner, 42 P3d, 135; Goins v West Group, 635 NW 2d 717 (Minn, 2001). Having said the above, however, I must acknowledge that I have co-authored an article on transgender law for Causes of Action - also a West publication. Meiselman, above n 19.

${ }^{225}$ Despite having a definition of "disability" which includes the transphobic federal exclusions, New Orleans does otherwise prohibit discrimination based on "gender identification." Compare NEW ORLEANS, LOUISIANA MUNICIPAL CODE $§ 86-1.5$; with $\S \S 86-22$ and 86-33.

${ }^{226}$ This is just one of many problems that I've yet to hear addressed by proponents of the 'transgendered people should rely on state and local law until a gay-only ENDA can be amended' strategy.
} 


\section{WHY?}

We are definitely advancing. ${ }^{227}$

Some states will move toward equality, while some will resist and even regress. $^{228}$

Transphobia is not the only form of intra-GLBT-community bigotry that has ever been observed or asserted to exist. Early on, there were more than a few complaints about misogyny. For example, Martha Shelley, one of the founders of the Gay Liberation Front, was particularly disgusted over the habit of Dick Leitsch, head of the New York Mattachine Society at the time of Stonewall, of loudly inquiring, 'Who opened the tuna fish?' when women would enter the room. ${ }^{229}$ And, sadly, racism is still not absent. ${ }^{230}$ Yet, despite rote acceptance of ' $\mathrm{T}$ ' into the acronym, transphobia is by far the most pervasive - both by commission and by omission.

Both of the italicised quotes above appeared in the Advocate and are about the gayled push for gay marriage - the first quote being from 1997, the second from 2004. Both were uttered by the same person: Even Wolfson, one of the most visible pushers of the gay marriage agenda. The second is a bit closer to reality - yet doesn't, in and of itself, reflect exactly whose rights are regressing. Though the quest for gay marriage may be in regression, such regression also involves a moving backward for transgendered people - more particularly, for transsexuals' identity and marital rights.

As for who and/or what is moving forward?

In 1999, the National Gay-Lesbian Task Force (NGLTF) determined that it could no longer support ENDA if it is not transgender-inclusive - unquestionably a move forward in the quest for transgender rights. To this position, Jeff Epperly, editor of Boston's Bay Windows responded:

In some ways, NGLTF's stance is admirable. Certainly there ought to be laws that protect people based on gender expression. Since so many of us are attacked because of unimportant personal characteristics, we empathize

\footnotetext{
227 'Death of a Gay Marriage Ban', The Advocate, 29 April 1997, 16 (quoting Evan Wolfson, then of LLDEF's Marriage Project).

${ }^{228}$ Mike Hudson, 'Marriage Gets Real', The Advocate, 12 October 2004, 33, 35 (quoting Evan Wolfson, now of Freedom to Marry).

${ }^{229}$ Dudley Clendenin and Adam Nagourney, Out For Good (1999) 26.

${ }^{230}$ For example, see Mubarak Dahir, 'Racism in the Gay Ghetto', Bay Windows, 16 October 2003, <http://www.baywindows.com/news/2003/10/16/Columns/Racism.In.The.Gay.Ghetto-529916.shtml>; Laura Kiritsy, 'In This Liberal City, Gay Blacks and Whites Still Remain Mostly in Separate Worlds', Bay Windows, 28 February 2002, <http://www.baywindows.com/news/2002/02/28/LocalNews/ In.This.Liberal.City.Gay.Blacks.And.Whites. Still.Remain.Mostly.In.Separate.World-194217.shtml>; and Michele Forsten, 'Painting with a Limited Palette: When Gays are Racist', Bay Windows, 26 April 2001, <http://www.baywindows.com/news/2001/04/26/Opinion/Guest.Opinion-73314.shtml>.
} 
with those who are discriminated against similarly. We should support transgender efforts to build their own, distinct political movement. ${ }^{231}$

A clearer gay demand for separate but (presumably, though by no means certainly) equal can hardly be envisioned.

Fast forward five years.

In August 2004, the Human Rights Campaign (HRC) adopted a resolution pledging to no longer support legislation such as ENDA if the proposals are not transgenderinclusive. While I have severe problems with the wording of the resolution - wording that, in my view, gives HRC ample room to continue to work against the best interests of transgendered people while publicly professing to be our champion. ${ }^{232}$ HRC's August resolution certainly was a step in the right direction, one that, quite frankly I thought the organisation would never take (even if as a substanceless phantom gesture.) If for no other reason, the significance of this resolution can be evidenced by the conservative gay media attacks on HRC - attacks which were swift and vicious.

Abandoning common sense, the Human Rights Campaign announced in early August that it will no longer support federal legal protection for millions of gay workers unless the tiny number of transgendered workers get that protection, too. The decision is a slap in the face to gay Americans, who generously fund HRC, and who will now have to wait even longer for federal employment discrimination protection.

$\cdots$

HRC also defends its reversal on what it calls "pragmatic" grounds. The group's new executive director, Cheryl Jacques, argues that adding gender identity to ENDA is a matter of gay self-interest. She hypothesizes that an employer might fire a gay man solely because he's feminine in appearance and manner, rather than because he's gay. The employer could then produce gender-conforming gay employees to prove it tolerates such gays, escaping ENDA's sanctions.

That's a make-weight argument based on a very unlikely scenario. Where is this Dodo bird of an employer who loves gays but detests gender nonconformists? Jacques provides no real-world example, and I am aware of none. $^{233}$

\footnotetext{
${ }^{231}$ Jeff Epperly, 'Transgender Political Machinations', Bay Windows, 24 June 1999 <http://www.baywindows.com/news/1999/06/24/Editorials/Transgender.Political.Machinations34891.shtml> (emphasis added).

${ }^{232}$ As Miranda Stevens-Miller, Chair of It's Time, Illinois (a state transgender rights organisation), once observed regarding HRC 'support' of transgender concerns: "They demonstrate their support in ways that can be publicly flaunted, cost nothing, and impact no one." Katrina C Rose, 'The Elizabeth Birch Society', Texas Triangle, 24 September 1999 <http://www.txtriangle.com/archive/750/vpkatrose.htm> (quoting Miranda Stevens-Miller).

${ }^{233}$ Dale Carpenter, 'HRC and the End of ENDA', Texas Triangle, 20 August 2004.
} 
Well, for starters, the author of the above, gay Republican law professor Dale Carpenter, could start with conservative gay employers. Take the 1993 remarks of an unidentified lesbian who was a hiring partner in a San Francisco law firm:

[S]he is "relatively" out among "people who get to know me," she says. But she usually won't hire prospective associates who identify themselves as gay through participation in gay and lesbian groups or volunteer work.

"When I go [to] law schools and I look at people's resumes, if they've got heavy gay or lesbian activities on them, I'm not interested, she says. Its signalling something that makes you different."

Yes, this quote is now over a decade old. ${ }^{234}$ But, the sentiment still exists in some circles - and, as a hiring principle, when put into play, would not only yield out-ofhand rejection of those who are 'gay on the resume' (or TS on the CV) but, by extension, anyone who is visibly non-straight in any way (such as a not-perfectlypassable transsexual or even a perfectly passable one who has been unable to secure identity documentation that would not out her upon completing typical beginningof-employment paperwork), who has GLBT-related work experience or simply who is ethical and tells a potential law firm employer about an issue that an ethical attorney should discuss with potential clients, such as being transsexual.

Chris Crain, the executive editor of the Washington Blade, the flagship paper of gay media conglomerate Window Media declared in response to the HRC move that ENDA had been "trans-jacked," and that HRC's 'mind-boggling decision is wrong politically, legally and morally., 235

That last word is quite curious.

Morally?

His editorial contained the following passage:

Transgendered people in opposite-sex relationships can marry under the existing laws of many states. Should they be denied that freedom until same-sex couples can do likewise? Should heterosexual couples be prevented from marrying until same-sex couples can?

\footnotetext{
<http://www.txtriangle.com/archive/1246/vp1.htm> (last visited 23 September 2004).

${ }^{234}$ Jane Goldman, 'Coming Out Strong', Deneuve, June 1993, 24, 54. The irony that the original version of sexual orientation-based employment anti-discrimination protection in California derived from expression of one's sexual orientation - as a "political activity" - presumably would be lost on that lesbian employer. Gay Law Students Ass'n, v Pacific Tel. \& Telegraph Co., 595 P 2d 592 (Cal, 1979).

${ }^{235}$ Chris Crain, 'ENDA Gets Trans-Jacked', Washington Blade, 13 August 2004

<http://www.washblade. com/2004/8-13/view/editorial/enda.cfm>.
} 
It would be wrong and immoral for us to expect others to be treated unfairly until we are treated equally. ${ }^{236}$

He fails to mention that the number of states in which such opposite-sex couples can get married has been shrinking - solely because of the backlash against the gay marriage issue, which he has all-but-demanded that the entire GLBT movement join forces in pushing, to the exclusion of all else. ${ }^{237}$

Although in GLBT publications I have long pointed out the hypocrisy endemic in those who will push for gay marriage while opposing transgender-inclusion, it was not until letters in response to Crain's August $13^{\text {th }}$ editorial began to appear that it became clear that others were seeing the same hypocrisy. Robert R Sassor stated it succinctly: 'Crain oddly takes a stance that HRC should be incrementalist on workplace discrimination but all-or-nothing on marriage equality. ${ }^{, 238}$

Crain also failed to use (properly at least) the word "transsexual."239

This is significant.

Although the subject could fill an entire book, ${ }^{240}$ and though there is no single smoking gun, my feeling based on looking at gay discourse from the past three decades is that, however much gay organisations and the gay populace may now genuinely be embracing the concept that gender variance must be addressed in order for civil rights legislation to truly be inclusive and effective, those who control the gay rights industry still refuse to actually accept the reality of transsexualism.

Crossdressers? No problem.

Drag queens? No problem.

Transvestites? No problem.

Butch? No problem.

Femme? No problem.

Transsexualism? Problem.

\footnotetext{
${ }^{236}$ Ibid.

${ }^{237}$ Compare Chris Crain, 'It's All About Marriage - Like it or Not, Our Movement Needs All Efforts Focused on Winning Freedom to Marry, and Our Leaders and Their "Friendly" Politicians are Either With Us or Against Us', Houston Voice, 22 August 2003, <http://www.houstonvoice.com/2003/822/view/editorial/marrige.cfm>, with Peter Rosenstein, 'More Than Just Gay Marriage', Washington Blade, 5 September 2003, <http://www.washblade.com/2003/9-5/view/columns/marrige.cfm>.

${ }^{238}$ Robert R. Sassor, 'Attacks on HRC Unfair', Washington Blade, 3 September 2004, <http://www. washblade.com/2004/9-3/view/letters/>.

${ }^{239}$ Crain, 'Trans-Jacked', above n 235 (though he did use it in an 'example' earlier in the piece, he failed to do so when he addressed marriage - which is the one key area where "transsexual" specifically and not the broader "transgender" applies).

${ }^{240}$ And, I may indeed do so in my work, though in a somewhat different vein than Viviane Namaste's excellent work. Invisible Lives: The Erasure of Transsexual and Transgendered People (2000).
} 
As late as 2000, the Advocate allowed its prestigious 'Last Word' column to be used by transphobic right-wing lesbian Norah Vincent to issue a call for what can be legitimately described as trans-extermination (politically, if not physically). ${ }^{241}$ Even as recently as 2004 it took a concerted outcry from transsexual activists to convince Lambda Literary Foundation not to nominate J. Michael Bailey's The Man Who Would be Queen, a horrifically-flawed pseudo-science tract (one that is almost as homophobic as it is transphobic ${ }^{242}$ ), for a Lambda Literary Award. ${ }^{243}$

Moreover, there has never been any willingness on the part of the gay community at large, or by the organisations that set the gay rights agenda, to accept responsibility for the damage done to transsexuals by not only 1979's lesbian-authored Transsexual Empire ${ }^{244}$ but also general gay discourse beginning in the mid-1970's, which led to the currently-accepted manufactured reality of exclusion-acceptability. ${ }^{245}$

From its founding in 1967 to its purchase in 1975 by conservative gay male David Goodstein, ${ }^{246}$ the Advocate, while no one would confuse it with a purely transgender publication such as Lee Brewster's Drag, was not transphobic and certainly not trans-erasive. However, the Advocate's Goodstein-era coverage of 1976's M.T. $v$ J.T. is instructive as to how things changed. The most significant transsexual recognition decision of the decade was as off the radar to the Advocate as the FGTRA was to the mainstream American press in the 1940's. Of course, there was an excuse for the latter; the FGTRA is fictional, created as an illustration for the theory I explore in this article. However, M.T. v J.T. was, and is, real. While not conclusive in and of itself, how the Advocate dealt with this opinion offers a stark depiction of the place of transsexual marital rights in the 'gay agenda' or even the more narrow 'gay marriage agenda' of the mid-1970's - which is something essential to grasp prior to making any effort to interpret any anti-gay marriage statute enacted in response to that first modern push for same-sex marriage. ${ }^{247}$

\footnotetext{
${ }^{241}$ Norah Vincent, 'Cunning Linguists', The Advocate, 20 June 2000. The Village Voice also has provided a platform for her and, following the San Francisco Board of Supervisors' approval of transgender healthcare benefits in 2001, she wrote of the Board:

Apparently, they see transsexuals as a special case. What makes them a special case? The perception that plastic surgeries--which are considered mere exercises in vanity to nontranssexuals--are a means of self-realisation to transsexuals. Without them, transsexuals literally cannot be themselves.

Norah Vincent, 'Welcome to the Transsexual Age', Village Voice, 29 May 2001, 14. To be fair, however, the Advocate did allow two transsexual women to comment on the aftermath of the 2004 U.S. presidential election.

${ }^{242}$ See, 'Why the Bailey Controversy is Important', Transgender Tapestry, Winter 2004, 52; and Katrina C Rose, 'The Man Who Would be Janice Raymond', Transgender Tapestry, Winter 2004, 56.

${ }^{243}$ See generally WMBR Radio (USA), Gender Talk, 'No. 452' (15 March 2004).

${ }^{244}$ Janice Raymond, The Transsexual Empire (1979). See also, 'A Great Conspiracy?', Transgender Tapestry, Winter 2002, 31-32.

${ }^{245}$ Rose, Three Names, above n 179, 138-47.

${ }^{246}$ Clendenin and Nagourney, above n 229, 245.

${ }^{247}$ And, both the 1973 statute cited against Christie Lee Littleton in Littleton v. Prange and the 1980 statute utilised to J'Noel Gardiner's detriment in In re Gardiner, are such statutes.
} 
The published opinion in M.T. $v$ J.T. was issued on 22 March $1976 .^{248}$ The first issue of the Advocate with a cover date after $22 \mathrm{March}$, the 24 March issue, likely was actually already on the stands by the $22 \mathrm{March}$, meaning that, somewhat ironically in light of the point I'm seeking to establish, the issue that was current at the time of M.T. v J.T. actually did feature a story about a transsexual, albeit indirectly. One of the cover stories was an interview with actor Chris Sarandon, then an Academy Award nominee for his portrayal of MTF transsexual Liz Eden ${ }^{249}$ in the movie Dog Day Afternoon. ${ }^{250}$

No mention is made of M.T. v J.T. in the April $7^{\text {th }}$ issue. It is unclear when this issue would have gone to press - and, in all fairness, I do assume that a March $22^{\text {nd }}$ court decision occurred too late to appear in the April $7^{\text {th }}$ issue. This leaves the subsequent issue, that of April $21^{\text {st }}$, as the one in need of analysis.

Although the largest single portion of the cover of that issue is dedicated to an interview with actor (and former preacher) Marjoe Gortner, the U.S Supreme Court's March $29^{\text {th }}$ decision in Doe v Commonwealth's Attorney, ${ }^{251}$ which rejected an appeal of a ruling upholding Virginia's sodomy statute, ${ }^{252}$ is noted as being covered in the issue. ${ }^{253}$ The decision was regarded as being important enough to give it stand-alone status - apart from the "Newsline" section, which featured small news blurbs from across the country - occupying most of page $6 .^{254}$ The "Newsline" section from that issue did feature an item about a decision from a New Jersey appellate court, though not the M.T. v J.T. decision from the Appellate Division Rather, it was the New Jersey Supreme Court's March $25^{\text {th }}$ decision in State $v$ J.O. ${ }^{255}$ upholding a decision declaring the state's lewdness statute to be inapplicable to private conduct between consenting adults. ${ }^{256}$ Both Doe and J.O. certainly were worthy of being covered by the Advocate. However, these decisions occurred after M.T. v J.T. Yet, the transsexual marriage decision is not mentioned.

\footnotetext{
${ }^{248}$ M.T., 355 A2d at 204.

${ }^{249}$ The movie gives different names to the real-life characters who were involved in or, as was the case with Eden, simply knew those involved in the bank robbery attempted by John Wojtowicz and others in 1972. Compare, Dog Day Afternoon (Warner Bros. 1975); with, Wojtowicz v United States, $550 \mathrm{~F} 2 \mathrm{~d}$ 786 ( $2^{\text {nd }}$ Cir, 1977). The court opinion mentions Eden's male name, though, by this point, she had long since transitioned and undergone SRS. She died of AIDS in 1987. 'Dog Day Afternoon Transsexual Dies of AIDS', GLC Voice (Minneapolis), 16 November 1987, 2.

${ }^{250}$ Donald Von Wiedeman, 'Interview', The Advocate, 24 March 1976, 32.

251425 US 901 (1976).

252403 F Supp 1199 (ED Va, 1975). The strength of this decision was an issue a decade later during the Bowers $v$ Hardwick litigation. Hardwick v Bowers, $760 \mathrm{~F} 2 \mathrm{~d} 1202$ (11 $\left.1^{\text {th }} \mathrm{Cir}, 1985\right)$, rev'd, 478 US 186 (1986).

${ }^{253}$ Interestingly, the cover blurb includes the wrong page number for the interior story: 'No Privacy For Gay People, Supreme Court Rules, Page 8.' The Advocate, 21 April 1976, cover. The story actually was on page 6. See above n 254.

${ }^{254}$ David Aiken, 'High Court Cancels Gay Privacy Rights', The Advocate, 21 April 1976, 6. And, make no mistake: I am not criticising the Advocate for what they did cover. A US Supreme Court decision unquestionably merits coverage. My criticism is of what was not covered.

255355 A 2d 195 (NJ, 1976).

256 'N.J. Court Rules Private Lewdness Not Illegal', The Advocate, 21 April 1976, 10.
} 
At this point, one might ask if marriage in general was not part of the Advocate's agenda at the time. Whatever its position on the agenda may have been, it certainly was present; even this April $21^{\text {st }}$ issue contains in item about a gay man's announcement of his intention to run for a county commissioner's seat in El Paso County, Colorado. Prominent in the piece, however, was mention of his having been one of ' 12 gay men married in last year's brief string of legal marriages in Colorado. $^{, 257}$ M.T. $v$ J.T., an appellate court decision definitively upholding a transsexual marriage, however, is not mentioned.

Another legitimate consideration is whether M.T. $v$ J.T. received any publicity anywhere at the time it was issued. Certainly, if it went largely unnoticed even by mainstream media in a pre-Internet era, it might well be unfair to chide the Advocate for failing to notice the decision. However, M.T. v J.T. did not go completely unnoticed at the time. Focusing just on New Jersey, J.O. as well as Doe were covered by the Trenton Evening Times, with the latter of the two making the front page of all three editions of the paper. ${ }^{258}$ The coverage that M.T. v J.T. received was almost as significant: a front-page story in two of the three editions, ${ }^{259}$ and mentioned on page three of the other. ${ }^{260}$ This was not isolated coverage; M.T. was also a front-page story in the Newark Star-Ledger. ${ }^{261}$

To be sure, the word transsexual does not apply to all gender-variant people. And, indeed, transgender is a very useful umbrella term - even though I have encountered a number of transsexuals who hate the word and refuse to have anything to do with it (so much so that they refuse to be involved with political efforts to ensure their rights because such politics is generally referred to as 'transgender' politics.) However, transsexuals cannot be ignored - and neither can transsexualism.

Transsexuals exist - and transsexual-specific (and, ore importantly, transsexualpositive) law exists: 25 recognition statutes, a number of non-statutory prorecognition birth certificate decisions, pro-transsexual criminal law decisions and what should be the ultimate for an incrementalism-addicted, marriage-minded movement - marriage recognition, the vast majority of which has gone unchallenged for over a quarter-century.

But, to acknowledge M.T. v J.T. is to acknowledge transsexual law.

\footnotetext{
${ }^{257}$ Untitled Newsline item, The Advocate, 21 April 1976, 10.

${ }^{258}$ Linda Mathews, 'Homosexuals Lose High Court Appeal of Privacy Case', Evening Times (Trenton, N.J.), 30 March 1976, A1 (Late Final and Bucks editions); Linda Mathews, 'High Court Rules Against Homosexuals', Evening Times (Trenton, N.J.), 30 March 1976, A1 (State Edition).

J.O. was covered in 'Sex Not Lewd if Not Seen, Court Says.' Evening Times (Trenton, N.J.), 26 March 1976, A8. During my research, however, I neglected to note which edition(s) of the paper in which this item appeared.

${ }^{259}$ Steven Ford, 'Gender Change Legalized', Evening Times (Trenton, N.J.), 22 March 1976, A1 (Late Final and Bucks editions).

260 'Sex Change No Barrier to Alimony', Evening Times (Trenton, N.J.), 23 March 1976, A3 (State Edition).

${ }^{261}$ Joshua McMahon, 'Transsexuals Granted a Full Range of Rights', Star-Ledger (Newark, N.J.), 23

March 1976, 1.
} 
To acknowledge transsexual law is to acknowledge successful transsexual law.

To acknowledge successful transsexual law is to acknowledge successful transsexuals - and it is to acknowledge that a flipside exists to the concept of 'incremental progress', a flipside in which gays and lesbians, and not the transgendered, constitute the increment that has, rightly or wrongly, been left behind.

Above all else, however, to acknowledge the above, is to acknowledge that there is at least the slightest of possibilities that transsexuals are equal to gays and lesbians. I firmly believe that this last acknowledgement is something that the organised American gay rights industry (as opposed to incredibly transsexual-friendly individuals therein, even the organisations I criticise in this article - and there are indeed some) has yet to show that it is capable of expressing.

Considering the somewhat visceral (yet, I feel, necessarily so) tone of this section, I feel it wise to end it by noting that, in spite of the definitional differences between gays and transsexuals and in spite of the effort I have put into detailing (again, necessarily so), the differences between gay marriage and heterosexual transsexual marriage, anti-transsexual bigotry by gays is not (and has never been) solely a concern for transsexuals and other transgendered people. The following appeared as a letter to the editor in the San Francisco Bay Times in May of 2001:

I have a problem with people thinking I'm transsexual because of my height and body size. I'm not a transsexual but I get to see firsthand how trans people are treated. I had two lesbians come up to me and spit in my face, because they assumed I was like Brandon Teena. They didn't know me, didn't talk to me, had never seen me, but yet they made an assumption and spit in my face, calling me "a wannabe male" and all this stuff. And these weren't kids, they were old enough to be my mother!! I'm 22 years old.

And, he was a gay man. ${ }^{262}$ California hate crimes law at that time did encompass anti-transgender violence such as the act detailed above. ${ }^{263}$ Yet, had it not - and, just as with employment anti-discrimination law, there are many jurisdictions which include sexual orientation but not gender identity - the act by the lesbians, while still some degree of assault, would not have been subject to a hate crime enhancement; but, had the man responded in kind, and, in doing so, uttered one or more anti-lesbian epithets, conceivably he could be charged with an assault and be subject to a hate crime enhancement.

\footnotetext{
${ }^{262}$ David Rosen, 'How Trans People Are Treated (Hatefully)', San Francisco Bay Times, 17 May 2001, 16.

${ }^{263} 1999$ CA. LAWS Ch. 566.
} 
Separate and unequal. ${ }^{264}$

Transgender recognition?

Transsexual recognition?

Transgender inclusion?

Transsexual inclusion?

As the letter above illustrates, the life you save may be your own.

\section{CONCLUSION}

In the spring of 1972, John Lennon and Yoko Ono were in the United States - to deal with custody concerns over Ono's child from a previous marriage. However, they took advantage of their time in the US to appear on a number of talk shows. On May 12, ABC broadcast an episode of the Dick Cavett Show on which they had appeared - and on which they performed their then-current song Woman is the Nigger of the World. ${ }^{265}$ Even now, a song with such a title is controversial - and it was certainly so then. ABC didn't want to broadcast the segment in which Lennon and Ono perform the song but a compromise was struck in which Cavett inserted an advisory prior to the segment.

Prior to the actual performance of the song, Lennon explained where the idea for the song, and its title, came from - and why it should not be regarded as racially offensive. As part of this he read a statement from Rep. Ron Dellums, then Chairman of the Congressional Black Caucus:

If you define niggers as someone whose lifestyle is defined by others, whose opportunities are defined by others, whose role in society is defined by others, then good news! You don't have to be black to be a nigger in this society. Most of the people in America are niggers. ${ }^{266}$

Inspired by that, I have long been tempted to entitle a law review article Transsexual is the Nigger of the Gay World. Looking extensively at Louisiana newspapers from 1968, and seeing the commotion over the mere presence of one AfricanAmerican in a state's entire legislature reminds a person of just how powerful the issue of race was - and still is. Consequently, I've decided against such an inflammatory title in favour of one that I hope will point to potential positives that can

\footnotetext{
${ }^{264}$ For a look at how this works in the employment anti-discrimination context, see Rose, above n 179 , 147 , n. 271.

${ }^{265}$ John Lennon and Yoko Ono / Plastic Ono Band, 'Woman is Nigger of the World', on Some Time in New York City (Capitol 1972).

${ }^{266}$ ABC Television (USA), The Dick Cavett Show (12 May 1972) (statement attributed to Rep. Ron Dellums, as read by John Lennon) (audio track of broadcast on file with author).
} 
(and should) result from outside-the-box thinking as to the scope of existing protranssexual legislation.

Yet, I nevertheless find Dellums' words compelling in that even in 2004, transgendered people - and transsexuals in particular - find themselves being defined by others - both the public at large and certain people from within the gay rights movement.

Defined as to who we are. Defined as to how we must act when it comes to asking for relief from the religionist-inspired bigotry that limits the lives of not just GLBT Americans but the vast majority of all Americans.

Transgendered people are told to wait for legal protections while gays, lesbians and bisexuals are granted the protections which the transgendered are denied. Transgendered people are told that gays and lesbians will help add them to the laws which were initially written either to ignore, exclude, or pre-empt the rights of transgendered people. Yet, time and again, after seeing gay-only employment laws enacted it is seen that the next item on the agenda never becomes adding transgendered people to the existing employment law but instead the establishment of samesex marriage ${ }^{267}$ or, as was the case in the early 1990's, gays in the military.

Moreover, not only do transgendered people see the intense backlash against the push for same-sex marriage all but remove any chance of there being enough progressive legislators in a given state to add gender identity to the existing employment law, ${ }^{268}$ but this backlash has also generated anti-same-sex marriage laws - and transgendered people see these so-called Defense of Marriage Acts used to nullify not just transsexuals' marriages but our very existence in the eyes of the law. Currently in Kansas, that state's DOMAs, after having been used to civilly nullify J'Noel Gardiner's legal existence in 2002, are being used to criminalise a transsexual for utilising her conformed, post-transition documentation that the state of Kansas itself had issued! $!^{269}$

Yes, transgendered people are told to wait - but gays and lesbians have refused to wait for their day on issues which unquestionably face more opposition than employment anti-discrimination protection for transgendered people. ${ }^{270}$ And something more controversial than same-sex marriage can scarcely be imagined. It may well have had more of an impact on the 2004 American presidential election than

\footnotetext{
${ }^{267}$ Vermont activists are now expressing dissatisfaction with the state's civil union law - yet seem to be satisfied with the fact that the state's civil rights statute still has not been amended to include transgender rights. 'Vermont Activists Not Satisfied With Civil Unions', Advocate.com, 14 September 2004.

${ }^{268}$ As happened in Vermont after the Civil Union statute was enacted in 2000.

${ }^{269}$ Connie Parish, 'Gast Case to Get Non-Jury Trial', Leavenworth Times, 22 April 2004. As this article was going to press, however, Sandy Gast, the transsexual defendant, actually was found not guilty of false swearing. 'Judge Rules Not Guilty in Gast Case,' Leavenworth Times, 16 November 2004 (online bulletin).

${ }^{270}$ Sassor, above n 238.
} 
the fraudulent reasons put forward as justification for war with Iraq. ${ }^{271}$ And, it may well be the wedge issue that allows religionist conservatives to complete its quest to divide the African-American vote the same way that a different generation of conservatives used African-Americans themselves to divide the previously Democrat South. $^{272}$

Of the advice given by whites to blacks to abstain from violence in their quest for equality in the 1960's, Jean Genet said:

When white men use violence, violence is good. When blacks use it, they are considered animals. However, it so happens that the blacks have exposed the tricks of language, as they have exposed religious tricks, legal shams and social deformities. Blacks aren't afraid of words anymore, regardless of the coloration that whites might give them.

It is evident that recommending non-violence to blacks is an effort to retain the Christian vocabulary which has kept them imprisoned in passivity for so long. However Christian the whites are, they don't feel guilty about using guns. That is violence. Asking blacks in America to be non-violent means that whites are demanding a Christian virtue which they themselves do not possess. That means that whites are once again trying to dupe the blacks. $^{273}$

Similarly, gays and lesbians, by poking the sleeping dogs of American anti-gaymarriage sentiment (and anti-gays-in-the-military sentiment before that) before utilising their political machinations to aid transgendered people in securing basic protections, have demanded the virtue of patience from the transgendered that they themselves have shown that they do not possess. Doing so while telling transgendered people to wait while those in power are 'educated' on transgender issues by the same people - or at least their successors in political interest - who have kept them uneducated is the same class of trick, sham and deformity of which Genet wrote.

The fight for re-inclusion of transgendered people into the movement we helped establish at Stonewall has been disingenuously described by non-inclusionists as everything from riding gays" coattails ${ }^{274}$ to "self-sabotage"275 to "foolishness"276 to

\footnotetext{
${ }^{271}$ Deborah Rogers, 'All in the Timing', Texas Triangle, 5 November 2004, <http://www.txtriangle.com/archive/1305/vp4.htm> (last visited Nov. 16, 2004);Dean E Murphy, 'Some Democrats Blame One of Their Own', New York Times, 5 November 2004, A18; Josh Gerstein, 'Blame Game Emerges Over Role of Gay Marriage in Democrats' Loss', New York Sun, 5 November 2004, 7; James Dao, 'Same-Sex Marriage Issue Key to Some G.O.P. Races', New York Times, 4 November 2004, P5.

272 Star Parker, 'An Amendment to Stop Moral Decay', WorldNetDaily, 28 September 2004, <http://www.worldnetdaily.com/news/article.asp?ARTICLE_ID=40658> (last visited 28 September 2004).

${ }^{273}$ Jean Genet, 'Here and Now For Bobby Seale', Ramparts, June 1970, 30, 31 (Judy Oringer, transl.)

${ }^{274}$ Kim I. Mills, 'Gay Groups Realigining — Organization Asks Pedophiles to Quit', Wisconsin State
} 
'not what Gay pride is about ${ }^{, 277}$ to causing gay men to 'shudder to think where we will end up if the nation turns its attention to 'transgender chic.'278 Even worse, omission of gender identity and expression from ENDA has been likened to 'passing a copyright law that covers books, television shows, digital music, and videos, but omits a single CD manufactured in a leap year on a Thursday during a full moon. ${ }^{279}$

It is none of the above.

It is a demand for the same things that gays and lesbians have no problem demanding for themselves. And, if necessary executing this demand will include detailing how transgendered people's quest for equality has been publicly ignored and privately subverted for decades by the non-inclusionists - in city council meetings, in state legislatures and in Congress; indeed, anytime and any place that 'gay rights' legislation is considered.

By so detailing, we are right.

And, by so detailing, we are doing what little we can to save our lives - and our identities, not just from religionist hatemongers but also from an element of the traditionally-disaffected world of sexual minorities that should know better than to marginalise the weak into oblivion. The interpretational trend of DOMA legislation has created a very real sense of urgency to publicise the truth of how little input transgendered people - transsexuals in particular - have had in the gay rights movement, and that is a critical element in any analysis of any law which opportunistic conservative activist judges might want to apply to gays, lesbians, bisexuals and transsexuals. Sadly, it is only a matter of time before some such religionist opportunist on some court in some state decides that a state's adoption of an antisame-sex marriage statute or amendment wipes out the state's transsexual birth certificate statute, wiping out transsexual identities, marriages and (if my employment law theory proves viable) an avenue to civil rights remedies in states that gays and lesbians can only dream about achieving employment anti-discrimination protection in.

I strongly assert that the examination of transgender - and transsexual - legal history heretofore missing from gay rights discourse, will open eyes that need to be opened and fill gaps that make the entire GLBT legal framework far more solid.

Journal, 14 February 1994. Mills, then an Associated Press writer, eventually became 'Education Director' of HRC.

${ }^{275}$ Michael Alvear, 'The New Transgender Look - Selfishness and Self-Sabotage', Houston Voice, 16 July 1999, 11.

${ }^{276}$ Carpenter, above n 233.

${ }^{277}$ Beren DeMotier, "Trans" Issues Are Not What Gay Pride is About', Washington Blade, June 1998, 33.

${ }^{278}$ Jim Gilbert, 'Gay, Lesbian, Bisexual, Transgender...(Yadda, Yadda, Yadda)', Bay Windows, 21 May $1998,12$.

${ }^{279}$ Carpenter, above n 233. 
Just as this article does not purport to be a full exploration of that history, it does not purport not to be a visceral statement regarding how transsexuals have been treated both by our enemies and by many who claim to be our friends. I do, however, hope that it serves to prevent future disasters in transgender law and to open the eyes of transgendered people (as well as gays and lesbians) to the type of protransgender law that actually does already exist and that could be put to good use for transgendered people if we are given a platform within the well-funded gay rights movement to sound the clarion call.

In short, I hope that it will benefit all transsexuals, all transgendered people and, yes, all gays, lesbians and bisexuals. Believe it or not, my aim is to unite, not divide. I realise that, after the past four years, such a phrase coming from someone associated with Texas (I no longer live there but I was born there and am still licensed to practice law there) may seem unbelievable. I assure all, however, that my desire is genuine.

Some people who claim to be from Texas actually are from Texas - and some of us can actually tell the truth. 